\title{
Design, Materials, and Mechanobiology of Biodegradable Scaffolds for Bone Tissue Engineering
}

\author{
Marco A. Velasco, ${ }^{1}$ Carlos A. Narváez-Tovar, ${ }^{1,2}$ and Diego A. Garzón-Alvarado ${ }^{2}$ \\ ${ }^{1}$ Studies and Applications in Mechanical Engineering Research Group (GEAMEC), Universidad Santo Tomás, Bogotá, Colombia \\ ${ }^{2}$ Biomimetics Laboratory and Numerical Methods and Modeling Research Group (GNUM), Instituto de Biotecnología (IBUN), \\ Universidad Nacional de Colombia, Bogotá, Colombia
}

Correspondence should be addressed to Marco A. Velasco; marcovelasco@usantotomas.edu.co

Received 4 November 2014; Accepted 27 January 2015

Academic Editor: Xuejun Wen

Copyright (C) 2015 Marco A. Velasco et al. This is an open access article distributed under the Creative Commons Attribution License, which permits unrestricted use, distribution, and reproduction in any medium, provided the original work is properly cited.

A review about design, manufacture, and mechanobiology of biodegradable scaffolds for bone tissue engineering is given. First, fundamental aspects about bone tissue engineering and considerations related to scaffold design are established. Second, issues related to scaffold biomaterials and manufacturing processes are discussed. Finally, mechanobiology of bone tissue and computational models developed for simulating how bone healing occurs inside a scaffold are described.

\section{Introduction}

Bones are rigid organs that consist of osseous tissue, bone marrow, endosteum, periosteum, cartilage, nerves, and vascular channels constituting the skeleton of vertebrate animals. Osseous tissue, which fulfills mechanical functions, is formed by connective tissue cells such as osteocytes, osteoblasts, and osteoclasts $[1,2]$ in an extracellular matrix composed mainly of minerals, proteins, and water. The bone composition and configuration will vary according to factors such as the anatomical location, supported load, age and gender of the individual, and the possible diseases that he or she could suffer $[3,4]$. In regard to bone composition, mineral phase is between 60 and $70 \mathrm{wt} . \%$ and water between 5 and $10 \mathrm{wt} . \%$, while the remaining portion is an organic matrix of collagen and other proteins.

The mineral phase of bone is essentially a calcium phosphate, called hydroxyapatite, presented in the form of nanocrystals with sizes between 25 and $50 \mathrm{~nm}$ in length [5]. Variations in the chemical composition of hydroxyapatite modify its physical properties, specially its solubility [6]. On the other hand, its biochemical properties mainly depend on the organic phase of the extracellular matrix of bone. Approximately $90 \%$ of the organic phase is formed by type I collagen. The remainder consists of proteins, lipids, and other macromolecules such as growth factors, cytokines, osteonectin, osteopontin, osteocalcin, osteoinductive proteins, sialoproteins, proteoglycans, phosphoproteins, and phospholipids [7-9]. Mineral and organic phases determine the mechanical properties of bone as a composite.

According to its structure, osseous tissue may be cancellous (trabecular) or cortical (lamellar). Cancellous bone is a network of interconnected porosities, ranging between 50\% to $90 \%$ of void space, with a solid portion which is formed of struts and plates that can adopt different configurations. It is located at the epiphysis of long bones and the interior of cuboid bones. Cortical tissue is located at the bone surface and it has a homogeneous and compact macrostructure. It is found mainly at the bone diaphysis and its thickness varies according to the bone anatomical location. Cortical bone consists of structural and functional units called osteons or Haversian systems. Osteons are arranged along the bone. Inside the osteons, there are small spaces or lacunae where osteocytes are housed. Osteons contains tiny channels or canaliculi to provide nutrient and oxygen to the cells. Along the center of the osteons there is a central channel with vessels and nerves. 
TABLE 1: Mechanical properties of bone. From BandyopadyayGhosh [39] and Knudson [40].

\begin{tabular}{lcc}
\hline Property & Cortical bone & Cancellous bone \\
\hline Tensile strength (MPa) & $50-150$ & $10-100$ \\
Compressive strength (MPa) & $130-230$ & $2-12$ \\
Young's modulus (GPa) & $7-30$ & $0.02-0.5$ \\
Strain to failure (\%) & $1-3$ & $5-7$ \\
Shear strength (MPa) & \multicolumn{2}{c}{$53-70$} \\
Shear modulus (GPa) & \multicolumn{2}{c}{3} \\
\hline
\end{tabular}

Bones have mechanical, synthetic, and metabolic functions. The mechanical functions are protection of internal organs, body support, and interaction with muscles and tendons to generate body movement [5]. The synthetic function is conducted by the bone marrow, where both bone and blood cells are synthesized in a process called hematopoiesis [10]. Metabolic functions are related to act as a reservoir of calcium, phosphorus, growth factors and fat [11]. Besides, bone tissue helps to regulate $\mathrm{pH}$ level of blood releasing alkaline salts [12].

Referring to mechanical function, bones are the structural elements of the human body. Skeletal system supports loads due to the different activities of an individual as holding things, walking, pushing, and so forth. These loads induce tensile, compressive, or shear stresses on the bone tissue. More complex stresses such as those caused by bending or twisting of bone can be decomposed into the three basic aforementioned stresses. To study these stresses, bone mechanical properties such as elasticity modulus, compressive, and tensile strength are important. These properties are highly dependent on the position of the bone and the condition of the individual. Besides, mechanical properties of bone vary depending on the load orientation with respect to the orientation of the tissue (anisotropy) and the speed to which the load is applied (viscoelasticity) [3,13]. Reference [14] provides a good source of data and models of mechanical properties for different types of human bones. Some important mechanical properties are described in Table 1.

Another important physical property of osseous tissue is permeability that describes the porosity and interconnectivity of tissue. Permeability is estimated between $0.003-11 \times$ $10^{-6} \mathrm{~m}^{4} / \mathrm{N} \cdot \mathrm{s}$ for trabecular bone in humans and $0.9-7.8 \times$ $10^{-11} \mathrm{~m}^{4} / \mathrm{N} \cdot \mathrm{s}$ in cortical bone for canine and bovine animals [15]. A detailed explanation of permeability in bone can be found in $[16,17]$.

Bone tissue may suffer various diseases that can be caused by excessive load or hormonal deficiencies, among other reasons $[18,19]$. Bone tissue as an engineering material can fail because mechanical loads originate stresses over the limits a healthy bone can bear or because the mechanical properties of bone are decreased by various pathologies making the bone weak and prone to be damaged. Some of the diseases of bone tissue are as follows.

(i) Fracture: it is partial or total loss of bone continuity. It is caused by traumas by mechanical loads that exceed the allowable stresses of the bone. There may be associated factors to the extent that allowable stresses are conditioned by other diseases that affect bone density. They can be classified considering the type of trauma, fracture shape, and the location and direction of the load [20].

(ii) Osteogenesis imperfecta: it is bone embrittlement due to deficiencies in the collagen matrix [21].

(iii) Osteoporosis: it is loss of bone minerals by hormonal deficiencies [22].

(iv) Osteomalacia or rickets: it is loss of bone mineral caused by nutritional deficiencies [23].

(v) Osteomyelitis: it is bone infection caused by bacteria $[24,25]$.

(vi) Cancer: primary or metastatic type causes progressive damage of bone tissue and its functions [26].

As mentioned above, those diseases affect multiple demographic groups according their socioeconomic conditions. For example, in developed countries the life expectancy of the population has increased considerably causing a rise in osteoporosis cases [27].

\section{Bone Tissue Engineering}

Tissue engineering combines the use of cells, engineering materials, and physicochemical factors to improve or replace the biological functions of damaged tissues or organs. It uses the principles and methods of engineering, biology, and biochemistry for understanding the structure and function of normal and pathological mammalian tissues and for developing biological substitutes in order to restore, maintain, or improve its function [28]. A wide area of interest for tissue engineering is the development of scaffolds that contribute to bone regeneration processes [29]. This development could follow some or all of the stages listed below [30]:

(1) scaffold fabrication;

(2) growth factor placement in the scaffold or damaged area;

(3) seeding of an osteoblast population into the scaffold in a static culture (petri dish);

(4) growth of premature tissue in a dynamic environment (spinner flask);

(5) growth of mature tissue in a physiologic environment (bioreactor);

(6) surgical transplantation of the scaffold;

(7) tissue-engineered transplant assimilation/remodeling.

The number and the way that previous stages are combined give complexity to the bone regeneration processes in tissue engineering. For scaffold fabrication, factors like size, mass, porosity, surface/volume ratio, form, surface shape, and chemistry of the element to be manufactured and composition, structure, molecular weight, and molecular orientation of the biomaterial must be considered. For stages 
that occur in in vitro environments, variables like culture medium, $\mathrm{pH}$, fluid flow, mechanical stimuli, temperature, origin of cells, number of cells, mobility of the cells, and cell activity affect the growth of new tissue. Finally, defect site, species, gender, age, inflammatory process, immunological process, mechanical stimuli, biochemical stimuli, enzymes, and vascularization determine the bone regeneration processes in in vitro environments [15].

2.1. Socioeconomic Considerations. In 2007 it was calculated that the whole area of tissue engineering consists of 50 companies employing 3,000 equivalent full-time positions [31]. In 2010 the number of companies related to regenerative medicines was increased significantly to 391, but only a small portion of these has a commercial product [32]. About 500,000 bone grafts are performed each year in the United States [33]. This quantity is close to the estimation that between $5 \%$ and $10 \%$ of the 6 million fractures that occurred in North America present delays or consolidation problems in the healing process [34].

Scaffolds, implants, biomaterials, cell based therapies, and growth factors are usually considered as bone grafts substitutes in bone tissue engineering. Diverse analyses show different market sizes and their growth rates depending of what it is denominated as bone graft substitute: the global bone graft substitute market was valued at \$1.9 billion in 2010 and it is forecast to reach $\$ 3.3$ billion in 2017 [35]. Another source states that the market for orthopedic biomaterials in the United States was almost \$3.4 billion in 2012 [36]. Another study affirms that $1 \mathrm{~g}$ of bone graft substitute costs approximately $100 \mathrm{USD}$ and the volume of materials is estimated close to 10 tons per year in 2010 [37]. The European market for bone graft substitute products for spinal fusion was valued at USD 177 million in 2010 and its growth rate is projected close to $17 \%$ per year, reaching an estimated value of $\$ 461$ million in 2016 [38]. The global bone graft substitute market consists of eight different segments [36]: orthopedic bone graft substitute, growth factors, stem cells, cell therapies, orthopedic hyaluronic acid viscosupplementation, orthopedic tendon graft, orthopedic cartilage repair, and spinal machined bone allograft. Growth factors represent the largest segment, close to $40 \%$ of the market. The segments related to synthetic materials represent only about $15 \%$ of the market, but their growth rate is the largest (close to 15\% per year) [37].

The cost of replacing organs was estimated in $8 \%$ of the worldwide cost of health in 2009 [41]. The high cost of tissue engineering is associated not only with research and development but also with the regulations governing human healthcare products [42]. Besides, some reasons for the size and growth rates of the bone tissue engineering markets are an aging but more active population, the increase of overweight issues in population, the increased interest of individuals in their own healthcare, the improvement of public health systems around the world, and the development of orthopedic procedures for people of all ages [43].

2.2. Growth Factors. Growth factors are substances, like cytokines or hormones, which act as biochemical signals capable of triggering cellular processes like growth, proliferation, or differentiation, among others. The most considered growth factors in bone tissue engineering are listed below.

(i) Bone morphogenetic proteins (BMPs): BMPs are a family of cytokines that stimulates the proliferation of chondrocytes and osteoblasts and increases extracellular matrix production. BMPs induce the differentiation of mesenchymal stem cells into osteoblasts. BMPs allow not only skeletal tissue formation during embryogenesis, growth, and adulthood, but also bone healing process. In newborns' skeletons, BMPs can be found in the collagen fibers of the bone matrix and also in cells located in the periosteum and the bone marrow. After a fracture, BMPs growth factors diffuse from bone matrix and activate osteoprogenitor cells which, in turn, produce more BMPs [44]. The BMP 2, BMP 4, and BMP 7 are the only growth factors that can singly provoke bone formation in in vitro cultures and at in vivo heterotopic sites. BMPs 1-3 increase the production of collagen type I and osteocalcin in in vitro osteoblasts like cells and improve the formation of mineralized bone nodules from bone marrow mesenchymal stem cells [45]. BMPs are the most representative bone graft substitute of growth factors segment due to their therapeutic possibilities $[31,41,46]$. Studies of the combined application of BMPs and porous scaffolds indicate that these growth factors promote growth of new bone tissue inside these structures [47-51].

(ii) Fibroblast growth factors (FGFs): FGFs stimulate the proliferation of mesenchymal cells, osteoblasts, and chondrocytes. FGFs enhance growth of different tissues due to their angiogenic properties. FGF-2 or bFGF is the most studied cytokine of this family for bone regeneration applications [51, 52].

(iii) Insulin-like growth factors (IGFs): IGFs promote the proliferation of osteoblasts and chondrocytes and induce matrix secretion from both cell types [51]. IGFs stimulate collagen synthesis and mineralization of bone tissue [53].

(iv) Platelet-derived growth factors (PDGFs): PDGFs increase the proliferation of chondrocytes and osteoblasts. However, depending on their concentrations levels, they have also been implicated in bone resorption [51]. PDGFs act as chemotactic and mitogenic factor for osteoblasts and other cells [54].

(v) Transforming growth factors- $\beta$ (TGFs- $\beta$ ): TGFs- $\beta$ cause the differentiation of mesenchymal cells into chondrocytes and may also induce chondrocyte and osteoblast proliferation [55]. Like PDGFs, they have been seen to increase bone resorption at certain concentrations playing a role in coupling bone formation and resorption activities [51].

2.3. Scaffolds. Scaffolds are fundamental devices for the regeneration of lost or damaged tissues and they have become an important tool in tissue engineering [56]. Their functions, 
from the mechanical point of view, consist of bearing external loads and giving shape to the tissue that is regenerated on it [57-59]. From the biological point of view, those structures support the development of extracellular matrix and cell colonization. In addition, scaffolds should allow transit of nutrient substances from the surrounding tissue or the culture media and waste disposal coming from the tissue being formed. Therefore scaffold stiffness, mechanical resistance, and permeability are important properties. An additional scaffolds' desirable feature may be a controlled degradation after they are implanted in order to get void space where new tissue can grow.

The mechanical properties and degradation of the scaffold depend on the material properties and the porosity geometry of its structure; meanwhile permeability depends on its structure. The mechanical properties of the scaffold must be similar to the properties of the replaced bone tissue in order to prevent stress shielding. Finally, the degradation rate must be as close as possible to the tissue growth rate to maintain stable properties in the tissue-scaffold compound during the regeneration process.

2.3.1. Design Considerations. A bioactive scaffold reacts in a controlled manner with its environment in order to stimulate specific biological responses where it is placed. The development of scaffolds to promote cellular growth inside them has been one of the fundamental goals of bone tissue engineering [30, 60, 61]. The biomechanical processes of bone regeneration are complex, so the requirements for scaffold design are diverse [12, 62-68]. Some of the most important design considerations are listed below.

(i) Biofunctionality: it is ability of the scaffold to meet the functional requirements for which it was designed, restoring the functions of the replaced tissue.

(ii) Biocompatibility: it is ability to support normal cellular activity including molecular signaling systems without eliciting or evoking local or systemic adverse effects to the host. Among the undesirable effects that must be eliminated, minimized, or controlled upon scaffold implantation in the body are cytotoxicity, genotoxicity, immunogenicity, mutagenicity, thrombogenicity, and swelling. For example, inflammation should be avoided because it can decrease the regeneration rate and promote tissue rejection.

(iii) Bioresorbability or biodegradability: it is ability to degrade with time in in vitro or in vivo environments, preferably at a controlled resorption rate in order to create space for new tissue to grow. In other words, it is expected that, as long as cells proliferate, void space in the scaffold increases and degradation rate of the material should match growth rate due to healing or regeneration process. It is related with biocompatibility because degradation products should be nontoxic and must be able to get metabolized and eliminated from the body. For example, the degradation behavior of the scaffolds should vary based on applications such as 9 months or more for scaffolds in spinal fusion or 3-6 months for scaffolds in craniomaxillofacial applications [69].

(iv) Mechanical properties: mechanical properties such as elastic modulus, tensile strength, fracture toughness, fatigue, and elongation percentage should be as close as possible to the replaced tissue (mechanical compatibility) in order to prevent bone loss, osteopenia, or "stress shielding" effect associated with the use of bone grafts. They are related to bioresorbability because the variation in mechanical properties due to degradation process should be compatible with bone regeneration process. A scaffold must have enough mechanical strength to retain its structure in order to comply with its mechanical function after its implantation in the case of hard, load-bearing tissues as bone. The large variation in mechanical properties as seen in Table 1 makes it difficult to design an "ideal bone scaffold."

(v) Pore size and porosity: a three-dimensional design affects the spatial distribution and location of cells, nutrients, and oxygen, thus affecting the viability of the new formed tissue. Porous scaffolds facilitate the migration and proliferation of cells, providing an appropriate microenvironment for cell proliferation and differentiation and allowing the mass transfer of nutrients, oxygen, and waste metabolic products within the structure. Scaffolds should have a large internal surface area due to overall porosity and pore size. The surface to volume ratio of porous scaffolds depends on the size of the pores. A large surface area allows cell adhesion and proliferation, whereas a large pore volume is required to contain and later deliver a cell population sufficient for healing or regeneration process. Mass transfer and cell migration will be inhibited if pores are not connected even if the overall porosity is high. Unfortunately, an increase in porosity causes a decrease of mechanical properties such as compressive strength and increases the complexity for scaffold manufacturing. On the other hand, osseous tissues typically have arranged on curved surfaces; therefore, to mimic this biomorphic pattern, pores are intended to have curved cross sections [12].

Comprehensive lists of terms related to tissue engineering and biomaterial are available in $[70,71]$. With regard to bone scaffolds, there are some specific features like the following.

(i) Osteoconductivity: it is ability to allow the bone cells to adhere, proliferate, and form extracellular matrix on its surface and pores [69]. This property is related to the biodegradability because the scaffold material must be reabsorbed to make space for the mature tissue that it initially helped to support. Besides, scaffolds act as a mold of the desired anatomical form.

(ii) Osteoinductivity: it is ability to induce new bone formation through biomolecular or mechanical stimuli, recruiting progenitor cells and allowing differentiation in a controlled phenotype or particular lineages [72]. 
(iii) Osteogenicity: it is ability to act as osteoblasts or mesenchymal cells (capable of deriving in an osteoblastic lineage) reservoir because these cells can form and mineralize the extracellular matrix of new osseous tissue.

(iv) Osteointegrity: it is ability to form strong bonds with surrounding osseous tissue allowing material continuity and proper transfer load.

Finally, additional functions for bone scaffolds could be as follows [73-75]:

(i) acting as carrier of drugs (i.e., antibiotics and/or antiinflammatories), growth factors, or cultured cells;

(ii) radiolucency: ability to differentiate radiographically with respect to the tissue where it was implanted;

(iii) formability: ability to be shaped by a manufacturing process in order to obtain the necessary internal and external geometry;

(iv) sterilizability: ability to ride out and facilitate a process of microbial destruction after being manufactured and before being used;

(v) stability on storage (shelf life): ability to preserve the physical, chemical, and dimensional properties within the estimated storage period between manufacture and its use.

The conflicting nature of the above desired characteristics was described by Karageorgiou and Kaplan [76] who reported that higher porosities induce greater bone ingrowth but lower mechanical stiffness and strength. Therefore, scaffold porosity must lie within a critical range small enough to maintain the mechanical integrity of the scaffold and large enough to provide optimal bioactivity [63].

2.3.2. Design Scales. The design and fabrication of scaffolds for bone regeneration applications attempt to obtain and control architecture at different levels due to external form and internal structure to meet the clinical requirements specified in the previous section. The architecture has different properties and characteristics depending on the dimensions of an element of the scaffold. Three basic scales refer to different features and processes.

The macro-mesoscale describes the geometry measured in millimeters. Among its features are the following [77-82]:

(i) scaffold external shape (appropriated to the site where it will be implanted);

(ii) mechanical properties;

(iii) density;

(iv) porosity: as a percentage of volume of the scaffold is empty.

The microscale describes features in the order of micrometers as

(i) pore size;

(ii) interconnectivity of pores and tortuosity;

(iii) degradability.
The features in nanometers include factors such as

(i) surface topology of the pores;

(ii) surface physical chemistry.

2.3.3. Porosity Design. Pore size and porosity are important geometric properties in scaffolds for bone regeneration because they affect the phenotype and the amount of tissues that grow on the construct. As mentioned before, interconnected pores are necessary for bone tissue regeneration because they allow migration and proliferation of osteoblasts and mesenchymal cells besides vascularization. It is observed that even a biomaterial like hydroxyapatite must have a porous structure in order to promote bone growth in vivo [83] or a high porosity to allow cell seeding in vitro [84]. Scaffolds implanted in vivo with pore sizes close to $100 \mu \mathrm{m}$ allow chondrogenesis but scaffolds with pores close to $350 \mu \mathrm{m}$ promote osteogenesis [85]. Although intensive research has been developed in both experimental and computational modeling, there are no final conclusions about the optimal porosity and pore size of a scaffold for bone regeneration. For example, the porosity range is between 50 and $90 \%$ for scaffolds that are not subjected to mechanical loads [86]; meanwhile the recommended size of the pores varies between 150 and $600 \mu \mathrm{m}$ [87], from 400 to $1200 \mu \mathrm{m}$ [88] and $350 \mu \mathrm{m}$ or above [76]. The variety of conclusions may be due to the complexity of the process of bone regeneration, which is multivariable and multiobjective [89].

Considering this and the emergence of solid-free form manufacturing methods to fabricate scaffolds [90] that allow controlling geometry characteristics better than other conventional methods like salt leaching there is an increasing interest in porosity design. Giannitelli et al. showed an extensive review of the design techniques used to create porous structures in the scaffolds noting that these geometries can be obtained in three ways [67]: periodic structures, nonperiodic structures, and optimization techniques. Periodic porous structures can be based on CAD systems for solid and surface modeling, such as constructive solid geometry (CSG) using primitives like cubes, cylinders, and spheres to represent the pores [91-97] and boundary representation (B-Rep) supported on facets and vertices [98]. In the last years, there is research about the use of implicit surfaces like triply periodic minimal surfaces [99-104] and space-filling curves like Hilbert curves [105]. Meanwhile, nonperiodic structures have been developed based on image of bone surfaces [77], trabecular bone portions $[106,107]$ or scaffolds [108], and stochastic methods and Voronoi diagrams [109]. The disadvantage of periodic and nonperiodic structures is the necessity of trial and error methods to determine if they are suitable for a particular purpose $[110,111]$. In contrast, optimization methods [112] using finite element methods obtaining porous structures considering different objectives as mechanical properties and permeability [59, 60, 113-115].

\section{Biomaterials for Bone Tissue Engineering}

A number of definitions have been developed for the term "biomaterials." One definition is "material exploited in 
contact with living tissues, organisms, or microorganisms" [71]. Another definition is as follows: "a biomaterial is a substance that has been engineered to take a form which, alone or as part of a complex system, is used to direct, by control of interactions with components of living systems, the course of any therapeutic or diagnostic procedure, in human or veterinary medicine" [116]. In general, biomaterials are intended to interface with biological systems to evaluate, treat, augment, or replace any tissue, organ, or function of the body and are now used in a number of different applications throughout the body. The major difference of biomaterials from other classes of materials is their ability to remain in a biological environment without damaging the surroundings and without being damaged in that process.

Naturally derived materials, ceramics, polymers and composites can be used as biomaterials. Natural biomaterials can be the bone from the same individual (autografts), from individuals of the same species (allografts) or from different species (xenografts). On the other hand, ceramic materials are based on calcium phosphates and bioglasses. They have good osteoinductive properties but low mechanical properties and difficulties in forming process. Polymers such as those derived from polyglycolic acid (PGA) and polylactic acid (PLA) have easy formability, good mechanical properties and biodegradability which may vary according to their molecular weight but low osteoinductive capacity. For their part, ceramic-polymer composite materials allow obtaining a biodegradable material, with good mechanical strength, osteoinductive, osteoconductive, and conformability properties combining the properties of each material family. Here we mention some of them.

3.1. Grafts. A biomaterial commonly used for bone regeneration is osseous tissue taken from the same individual (Autografts). Autografts are considered the "gold standard" because they are osteoinductive, osteoconductive, and osteogenic. This material is normally taken from a site that is not under mechanical load such as the iliac crest. Autografts contain cells and growth factors that support the process of bone regeneration and do not exhibit risk of rejection and disease transmission [117]. Some drawbacks of autografts are the necessity of additional surgeries, possible infections, morbidity of the bone, pain, and its limited availability. Depending on the source of the osseous tissue there may also be allografts (tissue from individuals of the same species) or xenografts (tissue from individual of different species). Allografts presented benefits as ready availability and easy handling but require treatments such as freeze drying, irradiation, and washing with acid, among others, to prevent rejection by the receptor and remove any possible infections from the tissue to be implanted; these processes can affect their mechanical and biological properties. Xenografts that usually come from cows and coral [118] could be osteoinductive and osteoconductive and with low cost with high availability but have the disadvantages of immune response and risk of transmission of animal diseases [119].

3.2. Ceramics. Ceramic materials are a group of inorganic oxides and salts used in bone tissue engineering because of their similarity to the mineral component of bone in the case of calcium phosphate or because of their capacity of strength bonding to osseous tissues in the case of bioglasses [117]. Some ceramic materials used in bone regeneration are listed below.

Calcium Phosphates. Calcium phosphates are a family of minerals composed of calcium ions $\left(\mathrm{Ca}^{2+}\right)$, orthophosphates $\left(\mathrm{PO}_{4}{ }^{3-}\right)$, metaphosphates or pyrophosphates $\left(\mathrm{P}_{2} \mathrm{O}_{7}{ }^{4-}\right)$, and sometimes hydrogen or hydroxide ions. The most common calcium phosphates for tissue engineering are hydroxyapatite (HA), calcium sulphate hemihydrate ( $\mathrm{CSH})$, gypsum, calcium sulphate dehydrate (CSD), calcium carbonate, dicalcium phosphate (DCP), octacalcium phosphate (OCP), $\beta$ tricalcium phosphate $(\beta$-TCP), biphasic calcium phosphate (BCP), and $\beta$-calcium pyrophosphate ( $\beta$-CPP) [37]. Commercially available calcium phosphates proceed from natural or synthetic sources and are processed in many physical forms like particles, blocks, cements, and coatings on metal implants or composites with polymers.

The most common calcium phosphate for bone tissue regeneration is hydroxyapatite (HA) which is a crystalline calcium phosphate $\left(\mathrm{Ca}_{10}\left(\mathrm{PO}^{4}\right)_{6}(\mathrm{OH})_{2}\right)$ present in bones. Depending on its source, it can be natural or synthetized, for example, it can be produced from calcium carbonate and monoammonium phosphate at ambient pressure [120] or from natural sources like cattle or coral [121]. Some HA presentations exhibit a very similar bone structure with osteoconductive characteristics allowing connective tissue surrounding and start the regeneration process.

Calcium phosphates are bioactive materials because of their ability to form bone apatite like material or carbonate hydroxyapatite on their surfaces. They have the ability to promote cellular function and expression besides the capacity of forming a strong bind between bone and biomaterial interface. In addition, calcium phosphates biomaterials processed in porous forms are capable of binding and collecting growth factors and become osteoinductive biomaterials [122, 123]. In addition, calcium phosphates are materials that allow adhesion of osteoblasts and promote mesenchymal cells migration. Related to degradation, tricalcium phosphates are capable of tunable bioresorption rate [124]. Different calcium phosphates can be used simultaneously to improve the scaffold performance [125].

Calcium phosphates applications in bone regeneration include their use as a scaffold in periodontal treatment, healing of bone defects, fracture treatment, total joint replacement, orthopedics, craniomaxillofacial reconstruction, and spinal surgery. Moreover, calcium phosphates are widely applied as a coating material to provide strength to polymeric scaffolds or to enhance the bioactivity on metal surfaces [121].

Bioglasses. Bioglasses are a family of bioactive glasses, compound of $\mathrm{SiO}_{2}, \mathrm{Na}_{2} \mathrm{O}, \mathrm{CaO}$, and $\mathrm{P}_{2} \mathrm{O}_{5}$ in variable proportions. There are several types of bioactive glasses: conventional silicates, such as bioglass 45S5, phosphate-based glasses, and borate-based glasses. A hydroxycarbonate apatite (HCA) layer is formed on the surface of the glass, following initial glass dissolution. HCA is similar to bone mineral and 
interacts with collagen to bind the bioglass with the host tissue. Osteoinductivity in bioglasses is related to the action of dissolution products of these biomaterials on osteoprogenitor cells stimulating new bone growth. Besides, the HCA layer provides a surface capable of enhancing osteogenic cell attachment and proliferation. As calcium phosphates, the HCA layer adsorbs protein and growth factors to promote new bone formation. An advantage of bioglasses above calcium phosphates is their faster degradation rate [126].

Bioglasses are used in bone regeneration like periodontal pocket elimination, alveolar ridge augmentation, maxillofacial reconstruction, spinal surgery, and otorhinolaryngological reconstruction $[127,128]$. They can be processed and manufactured to generate a range of three-dimensional scaffolds with different porosities and surface characteristics [117].

3.3. Polymers. In tissue engineering, biopolymers are synthetic organic materials which are biocompatible with humans. They may be of natural or synthetic origin. Among the natural polymers used for tissue regeneration are those materials inspired by the extracellular matrix like collagen [129]. Among the synthetic polymers used for bone tissue regeneration are polylactic acid (PLA), polyglycolic acid (PGA), and copolymers of PLA-PGA (PLGA). Properties of some polymers and copolymers biomaterials are listed in Table 2. A detailed list of commercial polymeric scaffolds' products can be found in $[130,131]$.

Collagen: collagen is the main component of connective tissue in mammals. Collagen type I is present in the form of elongated fibrils in bone and is the most abundant in nature and most considered for biomedical applications. It possesses good biocompatibility and low antigenicity. Collagen has the ability of crosslinking; therefore, mechanical and degradation properties can be tailored [129]. Collagen type I has Young's modulus of $5 \pm 2 \mathrm{GPa}$ for dry fibrils and from 0.2 to $0.5 \mathrm{GPa}$ for fibrils immersed in phosphate-buffered saline (PBS) [132].

Poly $(\alpha$-ester $)$ s: poly $(\alpha$-ester $)$ s are thermoplastic polymers with hydrolytically labile aliphatic ester bonds in their chains. Poly $(\alpha$-ester $)$ s can be developed from a variety of monomers using ring opening and condensation polymerization routes changing the monomeric units. Bioprocess methods can be used to develop some poly( $\alpha$-ester)s [133]. The poly( $\alpha$-ester)s are biodegradable, nontoxic, and biocompatible. Among poly $(\alpha$-ester $) s$, the most extensively investigated polymers are the poly( $\alpha$-hydroxy acid)s, which include poly(glycolic acid) and poly(lactic acid). The most extensively studied monomers for aliphatic polyester synthesis for biomedical applications are lactide, glycolide, and caprolactone [134]. Poly( $\alpha$-ester)s mainly are degraded by hydrolysis bulk erosion. The polymeric matrices degrade over their all cross section and have erosion kinetics that usually are nonlinear with discontinuities [135].

Polyglycolide (PGA) is a highly crystalline polymer (45$55 \%$ crystallinity); therefore, it exhibits a high tensile modulus with very low degradation rate due to organic solvents. The first biodegradable synthetic suture that was approved by the FDA in 1969 was based on polyglycolide [136]. Nonwoven polyglycolide scaffolds have been widely used as matrices for tissue regeneration due to their excellent degradability, good initial mechanical properties, and cell viability. High mechanical properties of PGA are due to its high crystallinity. Self-reinforced forms of PGA show higher stiffness than other degradable polymeric systems used clinically and exhibit an elasticity modulus of approximately $12.5 \mathrm{GPa}$. Polyglycolide degrades by nonspecific scissions of the ester chain. PGA loses its strength in 1-2 months when hydrolyzed and losses mass within 6-12 months. In the body, PGA degradation product is glycine which can be excreted in the urine or converted into carbon dioxide and water via the citric acid cycle [137]. Due to its good initial mechanical properties, polyglycolide has been investigated as bone internal fixation devices (Biofixs). However, the high rates of degradation and acidic degradation products limit the clinical applications of PGA. Therefore, copolymers containing PGA units are being developed to overcome those disadvantages.

Polylactide (PLA) is a chiral molecule and exists in two optically active forms: L-lactide and D-lactide. Their polymerization forms a semicrystalline polymer and PLA behaves as crystalline or amorphous depending of these stereoisomers. The polymerization of racemic (D,L)-lactide and mesolactide results in the formation of amorphous polymers $[138,139]$. The molar mass of the polymer as well as the degree of crystallinity has a significant influence on the mechanical properties [140].

Poly-L-lactide (PLLA) is a low rate degradation polymer compared to PGA and has good tensile strength and high Young's modulus (4.8 GPa approx.); therefore, it is useful for load-bearing applications, such as orthopedic fixation devices [134]. It has been reported that high molecular weight PLLA can take between 2 and 5.6 years for total resorption in vivo [144]. On the other hand, semicrystalline PLA is selected to the amorphous polymer when better mechanical properties are necessary. Semicrystalline PLA has an approximate tensile modulus of 3,5 GPa, tensile strength of $50 \mathrm{MPa}$, flexural modulus of $5 \mathrm{GPa}$, flexural strength of $100 \mathrm{MPa}$, and an elongation at break of about 4\% [145].

Poly(lactide-co-glycolide) (PLG): both L- and DLlactides have been used for copolymerization with glycolide monomers in order to obtain different degradation rates. PLG degradation rates depend on a variety of parameters including the LA/GA ratio, molecular weight, and the shape and structure of the matrix. For example, 50/50\% poly(DLlactide-co-glycolide) degrades in approximately 1-2 months, $75 / 25 \%$ PLG in $4-5$ months, and $85 / 15 \%$ copolymers in $5-6$ months. [146]. The popularity of these copolymers can be attributed to the FDA approval for use in humans and their good processability [134].

Polycaprolactone (PCL): PCL is semicrystalline polyester obtained by the ring opening polymerization of monomeric units of " $\varepsilon$-caprolactone." PCL presents hydrolytic degradation due to the presence of hydrolytically labile aliphatic ester bonds; however, the rate of degradation of homopolymer is rather slow (2-3 years) with respect to polymers like PLA. PCL has low tensile strength (approximately $23 \mathrm{MPa}$ ) and high elongation at breakage ( $>700 \%)$ [134]. It can be used in conjunction to other materials for load-bearing applications [147]. 
TABLE 2: Mechanical properties of typical polymers and copolymers for tissue engineering. From Maurus and Kaeding, Wu et al., and Middleton and Tipton [131, 137, 141].

\begin{tabular}{|c|c|c|c|c|c|c|c|}
\hline Materials & $\begin{array}{l}\text { Compressive/tensile } \\
\text { strength }(\mathrm{MPa})\end{array}$ & $\begin{array}{l}\text { Young's } \\
\text { modulus } \\
(\mathrm{GPa})\end{array}$ & $\begin{array}{l}\text { Elongation } \\
\quad(\%)\end{array}$ & $\begin{array}{l}\text { Melting } \\
\text { point }\left({ }^{\circ} \mathrm{C}\right)\end{array}$ & $\begin{array}{c}\text { Glass- } \\
\text { transition } \\
\text { temp }\left({ }^{\circ} \mathrm{C}\right)\end{array}$ & $\begin{array}{c}\text { Loss of } \\
\text { strength } \\
\text { (months) }\end{array}$ & $\begin{array}{c}\text { Loss of mass } \\
\text { (months) }\end{array}$ \\
\hline PLLA poly(L-lactide) & $28-2300$ & 4.8 & $5-10$ & 175 & $60-65$ & 6 & $24-68$ \\
\hline $\begin{array}{l}\text { PDLLA } \\
\text { poly(DL-lactide) }\end{array}$ & $29-150$ & 1.9 & $3-10$ & $165-180$ & $40-69$ & $1-2$ & $12-16$ \\
\hline $\begin{array}{l}\text { PGA } \\
\text { poly(glycolide) }\end{array}$ & $350-920$ & 12.5 & $15-20$ & 200 & $35-40$ & $1-2$ & $6-12$ \\
\hline $\begin{array}{l}\text { 85/15 DLPLG } \\
\text { poly(DL-lactide-co-glycolide) }\end{array}$ & & & & & $50-55$ & & $5-6$ \\
\hline $\begin{array}{l}\text { 75/25 DLPLG } \\
\text { poly(DL-lactide-co-glycolide) }\end{array}$ & $41.4-55.2$ & 2.0 & $3-10$ & Amorphous & $50-55$ & $1-2$ & $4-5$ \\
\hline $\begin{array}{l}\text { 65/35 DLPLG } \\
\text { poly(DL-lactide-co-glycolide) }\end{array}$ & & & & & $45-50$ & & $3-4$ \\
\hline $\begin{array}{l}\text { 50/50 DLPLG } \\
\text { poly(DL-lactide-co-glycolide) }\end{array}$ & & & & & $45-50$ & & $1-2$ \\
\hline PCL poly( $\varepsilon$-caprolactone $)$ & 23 & 0.4 & $300-500$ & 57 & $50-60$ & $9-12$ & $>24$ \\
\hline
\end{tabular}

3.4. Biocomposites. The literature review shows in recent years a trend in the development of scaffolds made of ceramic/polymer composites [142]. This is because ceramics like calcium phosphates have excellent osteoinductive properties but low degradability, low mechanical strength, and difficulty in forming processes for controlling the physical and geometrical characteristics required from the scaffold. Furthermore, polymers such as PLA exhibit poor osteoinductivity but better mechanical properties and degradability rates besides that they can be formed by various manufacturing processes that allow better control of their geometric characteristics. Composites of collagen type I and calcium phosphates are widely used in bone tissue engineering due to the similarity to natural bone and capacity of enhancing osteoblast differentiation and accelerating osteogenesis [143, 148, 149]. The development of ceramic-polymer composites allows biodegradable materials with good mechanical and biological properties as seen in Tables 3 and 4 .

3.5. Biomaterial Degradation. In the case of scaffolds made of biodegradable polymers, many resorption mechanisms are identified depending of the material type [37]. In those models water molecules diffuse into the polymer and break the link into polymer molecules. This phenomena cause a molecular weight decrease besides a decrease of elasticity modulus. After a certain threshold of molecular weight the polymer is considered completely degraded [57, 135]. A more elaborate model is proposed by Chen et al. [78] including autocatalysis. Han proposed a model that includes the effect of crystallization [160]. On the other hand, ceramics such as calcium phosphates and hydroxyapatite degrade by dissolution and osteoclasts effect as modeled in [161] (Table 5).

3.6. Scaffold Fabrication Techniques. Various manufacturing methods have been used to achieve certain properties at different scales. These methods are classified into conventional and additive manufacturing methods. Conventional methods are solvent casting/particulate leaching, phase inversion/particulate leaching, fiber meshing/bonding, melt molding, gas foaming, membrane lamination, hydrocarbon templating, freeze drying, emulsion freeze drying, solution casting, and ceramic sintering. These methods use physicochemical phenomena to ensure internal structures with a variable pore size between 100 and 500 microns with porosities up to $90 \%$ [15]. They have the disadvantage that internal structure consists of randomly arranged trabeculae and physical properties as permeability vary and are difficult to control. In recent years, methods of additive manufacturing, also called rapid prototyping (RP) or solid free-form modeling (SFF), have been used for scaffold fabrication. Some of these methods are fused deposition modeling (FDM), three-dimensional printing or plotting (3DP), selective laser sintering (SLS) and stereolithography (SLA). These methods achieve large scaffolds with oriented structures but fail to obtain high porosity with small pores. Detailed lists of specific materials, processing methods, and properties obtained are given in $[15,130]$. On the other hand, an alternative to solid bone scaffolds is injectable bone cements $[162,163]$. These are mainly used in the fixation of prostheses and filling bone cavities and kyphoplasty treatments [164].

\section{Mechanobiology of Bone Tissue}

Mechanobiology studies show how mechanical stimuli influence the shape and structure of tissues of living beings, in particular, muscle, tendon, cartilage, and bone tissues [165]. Mechanical and biochemical stimuli influence proliferation, differentiation, and cell functions [166]. Therefore, mechanobiology would be useful to suggest clinical and tissue engineering strategies to control osseous tissue behavior. 
Table 3: Porous biocomposites used for bone tissue engineering. From Chen et al. [142] and Wahl and Czernuszka [143].

\begin{tabular}{|c|c|c|c|c|c|c|c|}
\hline \multicolumn{2}{|c|}{ Biocomposite } & \multirow{2}{*}{$\begin{array}{c}\begin{array}{c}\text { Percentage of } \\
\text { ceramic (wt.\%) }\end{array} \\
28 \text { to } 75\end{array}$} & \multirow{2}{*}{$\begin{array}{c}\text { Porosity (\%) } \\
75 \\
\end{array}$} & \multirow{2}{*}{$\begin{array}{c}\text { Pore size }(\mu \mathrm{m}) \\
>100\end{array}$} & \multirow[t]{2}{*}{$\begin{array}{c}\text { Strength } \\
(\mathrm{MPa})\end{array}$} & \multirow{2}{*}{$\begin{array}{c}\begin{array}{c}\text { Modulus } \\
(\mathrm{MPa})\end{array} \\
65 \\
\end{array}$} & \multirow[t]{2}{*}{$\begin{array}{l}\text { Ultimate } \\
\text { strain (\%) }\end{array}$} \\
\hline Amorphous CaP & PLGA & & & & & & \\
\hline$\beta$-ТCP & Chitosan-gelatin & 10 to 70 & & 322 to 355 & 0.32 to 0.88 & 3.94 to 10.88 & \\
\hline \multirow{4}{*}{$\mathrm{HA}$} & PLLA & 50 & 85 to 96 & $100 \times 300$ & 0.39 & 10 to 14 & \\
\hline & PLGA & 60 to 75 & 81 to 91 & 800 to 1800 & 0.07 to 0.22 & 2 to 7.5 & \\
\hline & PLGA & & 30 to 40 & 110 to 150 & & 337 to 1459 & \\
\hline & Collagen & Variable & $\sim 0$ & $\sim 0$ & $34-60$ & $0.44-2.82$ & \\
\hline \multirow{4}{*}{ Bioglass } & PLG & 75 & 43 & 89 & 0.42 & 51 & \\
\hline & PLLA & 20 to 50 & 77 to 80 & $\begin{array}{l}\text { Approximately } 100 \\
\text { (macro); } \\
\text { approximately } 10 \\
\text { (micro) }\end{array}$ & 1.5 to 3.9 & 137 to 260 & 1.1 to 13.7 \\
\hline & PLG & 0.1 to 1 & & 50 to 300 & & & \\
\hline & PDLLA & 5 to 29 & 94 & $\begin{array}{c}\text { Approximately } 100 \\
\text { (macro); } 10 \text { to } 50 \\
\text { (micro) }\end{array}$ & 0.07 to 0.08 & 0.65 to 1.2 & 7.21 to 13.3 \\
\hline \multirow{2}{*}{ Phosphate glass A/W } & PLA-PDLLA & 40 & 93 to 97 & \multirow{2}{*}{98 to 154} & \multirow{2}{*}{0.017 to 0.020} & \multirow{2}{*}{0.075 to 0.12} & \\
\hline & PDLLA & 20 to 40 & 85.5 to 95.2 & & & & \\
\hline Bioglass & PGS & 90 & $>90$ & 300 to 500 & 0.4 to 1.0 & & \\
\hline
\end{tabular}

TABle 4: Properties of bone graft substitutes. Adapted from Ma and Elisseeff [150] and Brown et al. [151].

\begin{tabular}{|c|c|c|c|c|c|c|}
\hline Property & Allograft & Polymers & Ceramics & Composites & Cell based therapies & Growth factors \\
\hline Biocompatibility & Yes & Yes & Yes & Yes & Yes & Yes \\
\hline Osteoconductivity & Yes & Yes & Yes & Yes & No & No \\
\hline Osteoinductivity & Yes & No & No & Yes & No & Yes \\
\hline Osteogenicity & Yes & No & No & No & Yes & No \\
\hline Osteointegrity & Yes & No & Yes & Yes & Yes & No \\
\hline Mechanical match & No & Yes & Yes & Yes & No & No \\
\hline
\end{tabular}

Bone tissue is formed by a process called osteogenesis [167]. In this process, cells capable of producing tissue interact with chemotactic factors to form bone. Firstly, osteoblasts secrete substances to form osteoid tissue or immature bone, a nonmineral matrix compound of collagen [168] and glycosaminoglycans. Subsequently, the matrix mineralization occurs by deposition of hydroxyapatite [169, 170]. During this process, some osteoblasts become trapped in the newly formed bone and become osteocytes surrounded by osteons. Osteocytes maintain the extracellular matrix and it is hypothesized that they act as a network sensing mechanical stimulus that activates the bone remodeling units (BMUs) formed by osteoblasts and osteoclasts.

Once the bone is formed, it can be remodeled or regenerated by mechanical and biochemical stimulus. Remodeling process took place in old bone when tissue is replaced by new one in order to support changing loads or to replace bone with microdamage. A turnover rate of $100 \%$ per year in the first year of life, $10 \%$ per year in late childhood [12], and near 5\% per year in adult life [171-173] is estimated. Regeneration allows the creation of new tissue when an injury or lack of continuity occurs, for example, in case of fracture [174-176]. Both processes are carried out by
BMUs [177-180], in which osteoclasts resorb deteriorated bone matrix and osteoblasts deposit new bone. Sometimes, those processes present disorders like in Paget's disease [181]. The processes of remodeling and regeneration are still under study because of the large number of physical and biological factors creating complexity in their interactions [13]. For example, it is hypothesized that osteocytes by piezoelectric phenomena respond to mechanical deformations or stresses and send signals to osteoblasts and osteoclasts so they engage and conform BMUs to perform the resorption or deposition of new bone [2].

Remodeling and regeneration require actions at different scales. The mechanosensitive/mechanoresponsive process starts in nanoscale or molecular level activating genes and signals in cells [182, 183], and it continues with a mechanotransduction process at cell level in nano-microscale activating electrical, chemical, or biochemical activity, for example, ion channels or integrins, the differentiation of mesenchymal cells into bone cells (osteocytes, osteoblasts, and osteoclasts), and the interactions of those cells in the bone deposition and resorption processes [184]. Finally, in a macroscale, stimuli determine the mechanical properties of bone tissue, bone shape, and magnitude of the loads they can 
TABLE 5: Resorption mechanisms for biomaterials for scaffolds used in bone regeneration. From Bohner [37]* .

\begin{tabular}{|c|c|c|}
\hline Material type & Material & Degradation mechanism \\
\hline \multirow{6}{*}{ Ceramic } & Bioglass & $\begin{array}{l}\text { Generally: very limited degradation } \\
\text { through partial dissolution }\end{array}$ \\
\hline & $\begin{array}{l}\text { Plaster of Paris } \\
\text { (= calcium sulphate hemihydrate, } \mathrm{CSH}) \\
\text { Gypsum }\end{array}$ & Dissolution \\
\hline & $\begin{array}{l}\text { Dicalcium phosphate dehydrate } \\
\text { (= calcium sulphate dihydrate, } \mathrm{CSD})\end{array}$ & $\begin{array}{l}\text { Dissolution and/or conversion into an } \\
\text { apatite }\end{array}$ \\
\hline & Calcium carbonate & $\begin{array}{l}\text { Dissolution or cell-mediated depending } \\
\text { on the mineral phase }\end{array}$ \\
\hline & $\begin{array}{l}\text { Dicalcium phosphate }(\mathrm{DCP}) \\
\text { Octacalcium phosphate }(\mathrm{OCP}) \\
\beta \text {-Tricalcium phosphate }(\beta \text {-TCP) } \\
\text { Biphasic calcium phosphate }(\mathrm{BCP}) \\
\text { Precipitated hydroxyapatite crystals } \\
\beta \text {-Calcium pyrophosphate }(\beta \text {-CPP; } \\
\beta \text {-Ca2P2O7) }\end{array}$ & Cell-mediated \\
\hline & Sintered hydroxyapatite & Practically no degradation \\
\hline \multirow{3}{*}{ Metal } & Magnesium (alloy) & Corrosion \\
\hline & Iron (alloy) & Corrosion \\
\hline & Tantalum, titanium & Practically no degradation \\
\hline \multirow[b]{2}{*}{ Polymer } & $\begin{array}{l}\text { Polylactides, polyglycolides } \\
\text { Polycaprolactone }\end{array}$ & Hydrolysis \\
\hline & $\begin{array}{l}\text { Cellulose } \\
\text { Hyaluronan } \\
\text { Fibrin } \\
\text { Collagen } \\
\text { Chitosan }\end{array}$ & $\begin{array}{l}\text { Transport to lymph nodes } \\
\text { Hyaluronidase } \\
\text { Plasmin } \\
\text { Collagenase } \\
\text { Lysozyme }\end{array}$ \\
\hline
\end{tabular}

${ }^{*}$ Reprinted from Materials Today, with permission from Elsevier [37].

support. One example of adaptation of shape and structure of bone due to mechanical loads is described in Wolff's law [185-187]. It states that bone adapts its internal and external form depending on the forces applied on it [188].

From the clinical point of view, mechanobiology is studied using in vivo and in vitro models. These methods can be expensive, time-consuming, and difficult to control and, in some cases, with ethical drawbacks. An alternative to these models are computational methods or in silico experiments. Computational mechanobiology studies the effect of mechanical stimuli in the differentiation, growth, adaptation, and maintenance of tissues, establishing qualitative and quantitative rules between the different variables involved in these processes. In computational mechanobiology numerical methods, generally finite element method, FEM, are used to solve systems of equations describing the relationships between the variables and parameters of the phenomena studied. Whereas some variables and parameters of these processes may not be measurable, trial and error methods are applied $[189,190]$.

4.1. Mechanical Stimuli Variables. A first task in computational mechanobiology is to determine which mechanical stimulus will serve as input variable. The mechanical stimuli that monitor the cells and the means they used to measure that signal are still debated [191-196]. Signals can be essentially volumetric deformation component (change in size) and a deviatoric deformation component (change in shape). Several researchers have proposed various types of mechanical signals: Frost proposed a minimum stress value in the osseous tissue to trigger a bone apposition process [197], and later, he changed the stress signal by a deformation signal $[198,199]$, Carter et al. propose the principal strain and hydrostatic stress as mechanical signal [200], Claes and Heigele use the principal strain and the hydrostatic pore pressure to study the fracture healing process [201], Lacroix and Prendergast use the deviatoric strain and fluid velocity to study tissue differentiation in fracture healing [202], and Huiskes et al. studied strain energy density or SED to predict bone remodeling [203]. The output variables help to describe the differentiation process (how many and which cell lines are produced), proliferation (which is the rate of growth), and adaptation and maintenance of tissues (position and mechanical properties of formed tissues).

4.2. Regeneration and Remodeling of Bone Tissues. The study of the bone regeneration process may consider tissue differentiation depending on the type and magnitude of the mechanical stimulus. There are four basic mechanoregulatory 


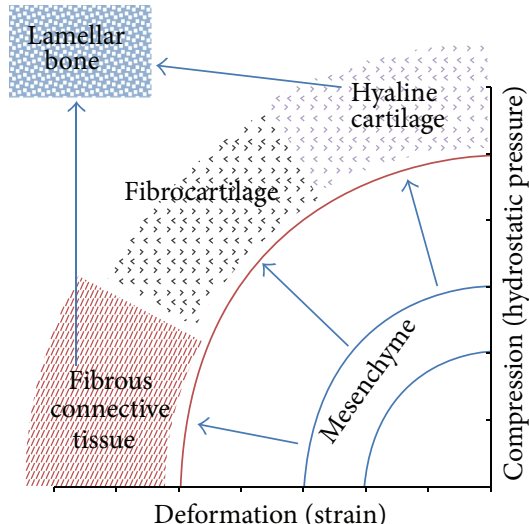

(a)

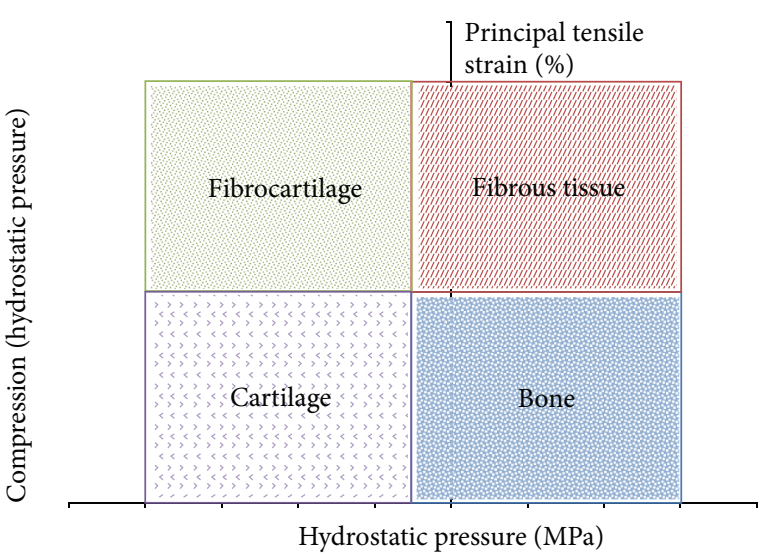

(b)

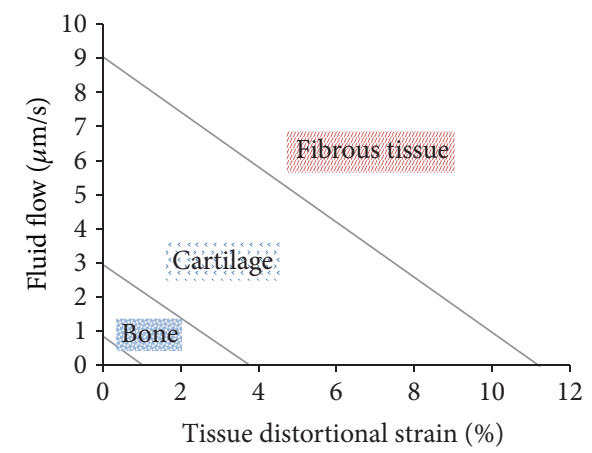

(d)

Figure 1: Graphic representation of mechanoregulatory models proposed by (a) Pauwels [204], (b) Carter et al. [200], (c) Claes and Heigele [201], and (d) Prendergast [205]. Adapted from Geris et al. [34] with permission from the Royal Society.

models of bone tissue differentiation. Pauwels postulated that high strains led to the formation of fibrous tissue, while higher pressures led to cartilage tissue [204]. Later, Carter et al. proposed a model where the type of tissue depends on the direction and magnitude of the stress. For example, the osseous tissue is possible where stresses and deformations have low magnitudes due to tension [200]. Claes and Heigele [201] developed a model that, unlike the previous two qualitative models, proposes ranges of values in which different types of tissues are obtained. For example, osseous tissue is generated by intramembranous ossification if the stress is $\pm 0.15 \mathrm{MPa}$ and the strain is less than $\pm 5 \%$. Finally, Lacroix and Prendegrast propose a model where tissues are not considered as a single material but as solid phase biphasic poroelastic materials. In this model, high fluid velocity values and deviatoric strains cause fibrous tissue [205]. Those models are represented in Figure 1.

Another line of research involves bone remodeling. This process includes the adaptation of the properties of the tissue that supports the mechanical loads. This line of work, developed by Fyhrie and Carter [206], has been extensively used in computational models. Here, bone tissue is considered as a continuous system with variable apparent density $(\rho)$. This apparent density is expressed in terms of the stress $(\sigma)$ to which the material is subjected. This is defined by the expression. It is considered that the bone tissue is a continuous system with variable apparent density $\rho$. This apparent density is expressed in terms of the stress $\sigma$ to which the material is subjected. This is defined by the expression

$$
\rho=A \sigma^{\alpha}
$$

where $A$ and $\alpha$ are constants. Considering $\alpha=0.5$, it follows that

$$
\sigma^{2}=2 E U
$$

where $E$ is the elastic modulus and $U$ is the strain energy density. With regard to the elastic modulus $E$, experimentation leads to the relationship

$$
E=c \rho^{3} .
$$

For example, one form of this equation that considers the viscoelastic behavior of the material is

$$
E_{\text {axial }}=C \dot{\varepsilon}^{0.06} \rho^{3},
$$

where $C$ is a constant that considers values of elastic modulus and density of reference while $\dot{\varepsilon}$ is the rate of deformation.

Therefore, considering that bone remodeling is an optimization problem follows that the strain energy and bone density are related by

$$
\rho=c^{\prime} U
$$


4.3. Other Processes. Besides bone regeneration and bone remodeling due to mechanical stimulus another processes must be considered in bone tissue engineering. Sengers et al. [207], in an extended review, analyze the processes listed below.

(i) Proliferation: it is growth of cell population due to mitosis. Exponential or logistic law is usually considered here $[153,155]$.

(ii) Nutrient transport and consumption: they are nutrient concentrations gradients due to cell population location and generation and disposal of waste substances. Regarding the interaction of nutrient availability and cell proliferation reaction diffusion equations is employed as seen in $[153,155]$.

(iii) Senescence: it is decrease of cell population due to apoptosis [184, 208].

(iv) Motility: it is cells movement and adhesion throughout their environment due to taxis. Although in bone remodeling and regeneration process it is usually considered that osteoblasts are not migrating cells, models as random walk or diffusion sometimes are applied. Random walk is a stochastic process that consists of a series of discrete steps of specific length. A random variable determines the step length and walk direction $[63,209]$. Diffusion processes are used to predict osteoblast movement [210] or Darcy's law to model movement in porous media [154].

(v) Differentiation: stem cells turn into other more specialized cell types. Regarding bone regeneration, mesenchymal cells turn into fibroblast, chondrocytes, and osteoblasts not only due to mechanical signal as mentioned above but also due to chemical factors.

(vi) Extracellular matrix changes: cells like osteoblasts produce matrix components (i.e., collagen and hydroxyapatite) and matrix degradation may occur by the action of osteoclasts.

(vii) Cell to cell interactions: cells can communicate with each other in order to trigger processes. For example, osteocytes act as receptors of mechanical or chemical signals and dispose the formation of BMUs.

4.4. The Mechanostat Theory. Frost suggests that bone change must be considered in two phases: the internal phase, where the bone tissue changes its density and so its mechanical properties and the external one where there are changes due to the deposition or removal of osseous tissue on the bone surface [197]. In both cases the remodeling process is active depending on the value of the mechanical stimulus. It can be seen that in a range of mechanical stimuli, remodeling is inactive [203].

For external remodeling, the rate at which a bone is deposited or removed is given by

$$
\frac{d X}{d t}=C_{x}\left(U-U_{n}\right)
$$

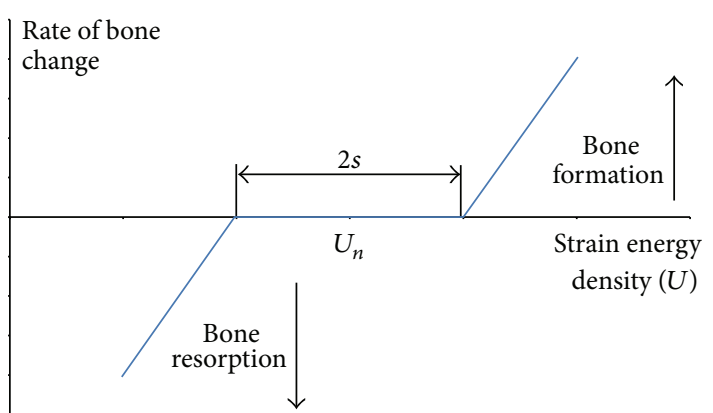

FIGURE 2: Rate of bone change as a function of the strain energy density $(U)$. From Frost [197].

where $X$ is the thickness of the formed layer, $U$ is the strain energy density (SED), $U_{n}$ is a reference value, and $C_{x}$ is proportionality constant. Similarly, Young's modulus $E$ change due to the mechanical stimulus is

$$
\frac{d E}{d t}=C_{E}\left(U-U_{n}\right) .
$$

Therefore, the description of external remodeling process (Figure 2) is given by

$$
\frac{d X}{d t}=C_{x}\left(U-(1+s) U_{n}\right)
$$

for $U>(1+s) U_{n}$ (Bone formation)

0 for $(1-s) U_{n}>U>(1-s) U_{n}$ (Lazy zone)

$$
\frac{d X}{d t}=C_{x}\left(U-(1-s) U_{n}\right)
$$

for $U>(1+s) U_{n}$ (Bone resorption).

Meanwhile, the elasticity modulus change for internal remodeling is expressed as

$$
\frac{d E}{d t}=C_{E}\left(U-(1+s) U_{n}\right)
$$

$$
\begin{gathered}
\text { for } U>(1+s) U_{n} \quad(\text { Stiffness increase) } \\
0 \text { for }(1-s) U_{n}>U>(1-s) U_{n} \text { (Lazy zone) } \\
\frac{d E}{d t}=C_{E}\left(U-(1-s) U_{n}\right)
\end{gathered}
$$

for $U>(1+s) U_{n}$ (Stiffness decrease).

This type of response model to mechanical stimulation is widely used in bone remodeling and bone regeneration simulations.

4.5. Adaptive Remodeling with Variable Loading Conditions. A drawback of the models previously discussed is that they do not propose how to consider the effect of variable loads. Jacobs et al. [211] suggest a model that considers the effect as

$$
\psi_{b}=\left(\sum_{i=1}^{n} n_{i} \bar{\sigma}_{b}\right)^{1 / m},
$$


where $n$ is the number of load cases considered, $n_{i}$ is the number of times that the load is applied per day, and $\bar{\sigma}_{b}$ is the average cyclic stress. On the other hand, the work of Carter et al. [212] contributes to bone remodeling models weighting the effect of various loads. The expression for the mechanical stimulus $S$ is

$$
S=\frac{1}{n} \frac{1}{\rho} \sum_{i=1}^{n} U_{i}
$$

where $U_{i}$ is the mechanical stimulus for the $i$ th load case, $n$ is the total number of load cases, and $\rho$ is the apparent density. Weinans et al. [213] used this stimulus to establish the change in bone bulk density by

$$
\frac{d \rho}{d t}=B(S-k)
$$

where $S$ is the stimulus with $B$ and $k$ as constants.

4.6. Bioinspired Models. In contrast to previous models, Mullender and Huiskes [214, 215] model the action of osteoblasts and osteoclasts separately. It is considered that the process of bone remodeling in a location $x$ at time $t$ is given by

$$
\frac{d m_{\mathrm{tot}}}{d t}=\frac{d m_{\mathrm{cl}}(x, t)}{d t}+\frac{d m_{\mathrm{bl}}(x, t)}{d t} .
$$

The variables $m_{\mathrm{cl}}$ and $m_{\mathrm{bl}}$ represent the adsorbed material by osteoclasts and deposited material by osteoblasts, respectively.

The second term represents the material apposition, which is given by

$$
\frac{d m_{\mathrm{bl}}(x, t)}{d t}=\tau(P(x, t)-k),
$$

where $P(x, t)$ is the stimulus received by the osteoblast from the osteocyte, $k$ is a reference value for the stimulus, and $\tau$ is a constant of proportionality. It should be noted here that the stimulus is not the value of the strain energy density at the point considered; it is the weighted summation of signals sent by osteocytes in the neighborhood around that point. Ruimerman et al. [216] applied this model to simulate bone adaptation under the influence of changes in the load orientation.

4.7. Mathematical Modeling of Bone Regeneration on Scaffolds. Considering the foregoing, there are two different and complex processes: first, scaffold degradation, which decreases its volume and mechanical properties; second, tissue regeneration that increases stiffness and mechanical resistance of new bone. Therefore, experimental [217-225] and computational models are required to show the system evolution over time and to help to identify the optimal initial properties of the scaffold when it is implanted $[78,79,108,111$, 114, 226-235].

Computer simulations allow analyzing scaffold properties and their effect on growth rate and mechanical behavior of the tissue. Those models vary as different properties, assumptions, domains, and solving approaches are considered. From the geometric point of view the most studied property is porosity [63, 236, 237]. The development of additive manufacturing methods has generated interest in the effect of the shape and size of the scaffold pores. In those studies, a representative volume element (RVE), instead of the whole model of the scaffold, is studied $[57,78]$. Simulations can be developed for different processes at different scales. At a nanoscale level, the mechanisms of cell adhesion to the walls can be studied $[80,81]$. In the microscale, the effect of the shape and size of the pores can be considered [57, 78], and, at the macroscale, the mechanical behavior of the scaffold $[77,79,238]$. Finally, the use of homogenization and multiscale methods has allowed the researching of various phenomena influencing the process of bone regeneration $[111,239,240]$ like substances transport [241, 242]. Some examples of computational mechanobiological models for fracture healing and bone regeneration on porous scaffolds are listed in Table 6.

\section{Discussion}

The global bone graft substitutes market is actually growing, mainly due to the population needs and the improvement of the health services. In this context, design and manufacture of biodegradable scaffolds are one of the major research and development interests in tissue engineering. This paper gives a review about the scaffold design considerations and requirements, the biomaterials that can be selected for a biodegradable scaffold and their related manufacturing processes.

During the scaffold design process there are many considerations to be made: biofunctionality, biocompatibility, biodegradability, mechanical properties, and porosity are among the most important ones. Designing a biodegradable scaffold is a complex process in three ways. First, there are contradictions between the design parameters which must be solved, for example, high porosity versus high mechanical stiffness. Second, the scaffold must be designed using patient-specific parameter values in order to satisfy its functional requirements; thus it is necessary to estimate individual porosity, pore size, and mechanical properties of the affected tissue. Third, the scaffold has to be designed as easy as possible to manufacture; therefore design for manufacturability concepts must be taken into account.

This review discussed many biomaterials and their manufacturing processes for biodegradable scaffold fabrication, but limited work has been done in order to obtain biomaterials with patient-specific degradation rate. One of the future challenges in bone tissue engineering is to design and to manufacture biodegradable scaffolds with a homogeneous growth rate over their entire volume, using pore size gradients or specific distributions of embedded growth factors. This requires manufacturing processes with higher resolution and biofabrication capabilities.

The mechanobiological computational models of the bone regeneration and remodeling processes can assist the design of biodegradable scaffolds because they can help to 
TABLE 6: Computational mechanobiological models for fracture healing and bone regeneration on scaffolds.

\begin{tabular}{|c|c|c|c|c|c|}
\hline Modeled phenomena & Input variable & Output variables & Material & $\begin{array}{c}\text { Cells } \\
\text { considered }\end{array}$ & Reference \\
\hline $\begin{array}{l}\text { Fluid motion of a bone } \\
\text { substitute applied to the } \\
\text { high tibial osteotomy with } \\
\text { three different wedge sizes }\end{array}$ & Fluid-induced shear stress & $\begin{array}{l}\text { Elastic modulus, Poisson's } \\
\text { ratio, porosity, and } \\
\text { permeability values that } \\
\text { optimize the internal fluid } \\
\text { motion }\end{array}$ & Not specified & Not specified & {$[152]$} \\
\hline $\begin{array}{l}\text { Cell growth } \\
\text { In vitro versus in silico }\end{array}$ & Local oxygen tension & Cell density & PLGA & Preosteoblast & {$[153]$} \\
\hline $\begin{array}{l}\text { Cell differentiation and } \\
\text { proliferation on } \\
\text { biodegradable scaffold }\end{array}$ & $\begin{array}{l}\text { Shear strain and fluidic } \\
\text { velocity }\end{array}$ & $\begin{array}{l}\text { Cell differentiation } \\
\text { Cell growth } \\
\text { Mechanical properties }\end{array}$ & PLGA & $\begin{array}{c}\text { Mesenchymal } \\
\text { cells } \\
\text { Osteoblast } \\
\text { Osteoclast } \\
\text { Chondrocyte } \\
\text { Fibroblast } \\
\end{array}$ & {$[58]$} \\
\hline $\begin{array}{l}\text { Cell growth on porous } \\
\text { scaffolds }\end{array}$ & Cell density & $\begin{array}{l}\text { Cell density } \\
\text { Pressure }\end{array}$ & Not specified & Not specified & {$[154]$} \\
\hline $\begin{array}{l}\text { Cell growth and } \\
\text { distribution }\end{array}$ & Cell density & $\begin{array}{l}\text { Cell density and } \\
\text { distribution }\end{array}$ & Not specified & Not specified & {$[155]$} \\
\hline $\begin{array}{l}\text { Cell differentiation and } \\
\text { proliferation on } \\
\text { biodegradable scaffold }\end{array}$ & $\begin{array}{l}\text { Porosity, Young's modulus, } \\
\text { and dissolution rate } \\
\text { Shear strain and fluidic } \\
\text { velocity }\end{array}$ & Cell differentiation & PLGA & $\begin{array}{c}\text { Mesenchymal } \\
\text { cells } \\
\text { Osteoblast } \\
\text { Osteoclast } \\
\text { Chondrocyte } \\
\text { Fibroblast }\end{array}$ & [63] \\
\hline $\begin{array}{l}\text { Cell differentiation and } \\
\text { proliferation on } \\
\text { biodegradable scaffold }\end{array}$ & $\begin{array}{l}\text { Scaffold stiffness, porosity, } \\
\text { resorption kinetics, pore } \\
\text { size, and preseeding }\end{array}$ & $\begin{array}{l}\text { Cell growth } \\
\text { Scaffold mass loss } \\
\text { Permeability } \\
\text { Porosity }\end{array}$ & Polymer & Not specified & [156] \\
\hline $\begin{array}{l}\text { Mechanical behavior and } \\
\text { drug delivery }\end{array}$ & $\begin{array}{l}\text { Stress loads according to } \\
\text { different position invivo }\end{array}$ & $\begin{array}{l}\text { Drug release } \\
\text { Stress }\end{array}$ & Hydroxyapatite & Not specified & [157] \\
\hline $\begin{array}{l}\text { Cell growth and } \\
\text { differentiation } \\
\text { over implant } \\
\text { porous surface }\end{array}$ & Force & Cell differentiation & Not specified & $\begin{array}{c}\text { Mesenchymal } \\
\text { cells } \\
\text { Osteoblast } \\
\text { Osteoclast } \\
\text { Chondrocyte } \\
\text { Fibroblast } \\
\end{array}$ & {$[158]$} \\
\hline $\begin{array}{l}\text { Proliferation and } \\
\text { hypertrophy of } \\
\text { chondrocytes in the growth } \\
\text { plate }\end{array}$ & Stress & Cell proliferation & Not specified & Chondrocyte & [159] \\
\hline
\end{tabular}

understand the effect of scaffold properties on bone ingrowth; therefore, their results can be used to optimize the scaffold structure in order to meet patient-specific mechanical and pore characteristics. A disadvantage of these models is that they involve many parameters whose values have to be estimated with in vitro or in vivo experimentation. It is necessary to rationalize the number of model parameters without loss of reliability of the numerical results.

\section{Conflict of Interests}

The authors declare that there is no conflict of interests regarding the publication of this paper.

\section{Acknowledgment}

This work is kindly supported by Universidad Santo Tomás, FODEIN Fund Code 056-2014

\section{References}

[1] J. E. Aubin and J. M. Heersche, "Bone cell biology osteoblasts, osteocytes, and osteoclasts," in Pediatric Bone, Elsevier, 2002.

[2] J. B. Lian and G. S. Stein, "The cells of bone," Proteins, 2006.

[3] S. Cowin, Bone Mechanics Handbook, CRC press LLC, New York, NY, USA, 2001.

[4] O. Fricke, Z. Sumnik, B. Tutlewski, A. Stabrey, T. Remer, and E. Schoenau, "Local body composition is associated with gender 
differences of bone development at the forearm in puberty," Hormone Research, vol. 70, no. 2, pp. 105-111, 2008.

[5] S. Weiner and H. D. Wagner, "The material bone: structuremechanical function relations," Annual Review of Materials Science, vol. 28, no. 1, pp. 271-298, 1998.

[6] L. C. Chow, "Solubility of calcium phosphates," Monographs in Oral Science, vol. 18, pp. 94-111, 2001.

[7] M. Wendel, Y. Sommarin, and D. Heinegård, "Bone matrix proteins: isolation and characterization of a novel cell- binding keratan sulfate proteoglycan (osteoadherin) from bovine bone," Journal of Cell Biology, vol. 141, no. 3, pp. 839-847, 1998.

[8] C. M. Gundberg, "Matrix proteins," Osteoporosis International, vol. 14, supplement 5, pp. S37-S42, 2003.

[9] P. G. Robey, N. S. Fedarko, T. E. Hefferan et al., "Structure and molecular regulation of bone matrix proteins," Journal of Bone and Mineral Research, vol. 8, supplement 2, pp. S483-S487, 1993.

[10] S. J. Morrison and D. T. Scadden, "The bone marrow niche for haematopoietic stem cells," Nature, vol. 505, no. 7483, pp. 327334, 2014

[11] J. F. Raposo, L. G. Sobrinho, and H. G. Ferreira, "A minimal mathematical model of calcium homeostasis," Journal of Clinical Endocrinology and Metabolism, vol. 87, no. 9, pp. 4330-4340, 2002.

[12] F. Barrere, T. Mahmood, K. Degroot, and C. Vanblitterswijk, "Advanced biomaterials for skeletal tissue regeneration: instructive and smart functions," Materials Science and Engineering R: Reports, vol. 59, no. 1-6, pp. 38-71, 2008.

[13] M. Pawlikowski, M. Klasztorny, and K. Skalski, "Studies on constitutive equation that models bone tissue," Acta of Bioengineering and Biomechanics/Wrocław University of Technology, vol. 10, no. 4, pp. 39-47, 2008.

[14] B. Helgason, E. Perilli, E. Schileo, F. Taddei, S. Brynjólfsson, and M. Viceconti, "Mathematical relationships between bone density and mechanical properties: a literature review," Clinical Biomechanics, vol. 23, no. 2, pp. 135-146, 2008.

[15] U. Meyer, T. Meyer, J. Handschel, and H. P. Wiesmann, Fundamentals of Tissue Engineering and Regenerative Medicine, Springer, Berlin, Germany, 2009.

[16] M. A. Meyers, P.-Y. Chen, A. Y.-M. Lin, and Y. Seki, "Biological materials: structure and mechanical properties," Progress in Materials Science, vol. 53, no. 1, pp. 1-206, 2008.

[17] M. Doblaré, J. M. García, and M. J. Gómez, "Modelling bone tissue fracture and healing: a review," Engineering Fracture Mechanics, vol. 71, no. 13-14, pp. 1809-1840, 2004.

[18] K. Piper and G. Valentine, "Bone pathology," Methods in Molecular Biology, vol. 915, pp. 51-88, 2012.

[19] N. Peel, "Bone remodelling and disorders of bone metabolism," Surgery, vol. 27, no. 2, pp. 70-74, 2009.

[20] J. L. Marsh, T. F. Slongo, J. Agel et al., "Fracture and dislocation classification compendium-2007: Orthopaedic Trauma Association Classification, Database and Outcomes Committee," Journal of Orthopaedic Trauma, vol. 21, no. 10, supplement, pp. S1-S133, 2007.

[21] F. Rauch and F. H. Glorieux, "Osteogenesis imperfecta," The Lancet, vol. 363, no. 9418, pp. 1377-1385, 2004.

[22] P. Meunier, Osteoporosis: Diagnosis and Management, Taylor \& Francis, London, UK, 1998.

[23] J. A. Eisman, “6 Osteomalacia,” Baillière’s Clinical Endocrinology and Metabolism, vol. 2, no. 1, pp. 125-155, 1988.
[24] P. J. Carek, L. M. Dickerson, and J. L. Sack, "Diagnosis and management of osteomyelitis," American Family Physician, vol. 63, no. 12, pp. 2413-2420, 2001.

[25] H. A. Mousa, "Bone infection," The Eastern Mediterranean Health Journal, vol. 9, no. 1-2, pp. 208-214, 2003.

[26] J. A. Buckwalter and E. A. Brandser, "Metastatic disease of the skeleton," The American Family Physician, vol. 55, no. 5, pp. 1761-1768, 1997.

[27] J. A. Buckwalter, J. D. Heckman, and D. P. Petrie, "Aging of the north American population: new challenges for orthopaedics," Journal of Bone and Joint Surgery-Series A, vol. 85, no. 4, pp. 748-758, 2003.

[28] R. Lanza, R. Langer, and J. Vacanti, Principles of Tissue Engineering, Academic Press, New York, NY, USA, 3rd edition, 2007.

[29] J. Hollinger, T. A. Einhorn, B. Doll, and C. Sfeir, Bone Tissue Engineering, CRC Press, 2004.

[30] D. W. Hutmacher, "Scaffolds in tissue engineering bone and cartilage," Biomaterials, vol. 21, no. 24, pp. 2529-2543, 2000.

[31] M. J. Lysaght, A. Jaklenec, and E. Deweerd, "Great expectations: private sector activity in tissue engineering, regenerative medicine, and stem cell therapeutics," Tissue Engineering - Part A, vol. 14, no. 2, pp. 305-315, 2008.

[32] G. Lewis, "Regenerative medicine at a global level: current patterns and global trends," in The Global Dynamics of Regenerative Medicine: A Social Science Critique, A. Webster, Ed., p. 248, Palgrave Macmillan, 2013.

[33] A. Greenwald, S. Boden, R. Barrack et al., "The evolving role of bone-graft substitutes," in Proceedings of the American Academy of Orthopaedic Surgeons 77th Annual Meeting, p. 6, 2010.

[34] L. Geris, J. V. Sloten, and H. van Oosterwyck, "In silico biology of bone modelling and remodelling: Regeneration," Philosophical Transactions of the Royal Society A: Mathematical, Physical and Engineering Sciences, vol. 367, no. 1895, pp. 2031-2053, 2009.

[35] Global Data, Bone Graft Substitutes-Global Pipeline Analysis, Competitive Landscape and Market Forecast to 2017, Global Data, London, UK, 2011.

[36] iData Research, U.S. Orthopedic Biomaterials Market, iData Research, Dallas, Tex, USA, 2013.

[37] M. Bohner, "Resorbable biomaterials as bone graft substitutes," Materials Today, vol. 13, no. 1-2, pp. 24-30, 2010.

[38] Medtech Insight/Elsevier Business Intelligence, "European markets for bone graft substitute products for spinal fusion," Tech. Rep. \#A329, Life Science Intelligence, Huntington Beach, Calif, USA, 2011.

[39] S. Bandyopadyay-Ghosh, "Bone as a collagen-hydroxyapatite composite and its repair," Trends in Biomaterials and Artificial Organs, vol. 22, no. 2, pp. 116-124, 2008.

[40] D. Knudson, Fundamentals of Biomechanics, Springer, Boston, Mass, USA, 2007.

[41] E. S. Place, N. D. Evans, and M. M. Stevens, "Complexity in biomaterials for tissue engineering," Nature Materials, vol. 8, no. 6, pp. 457-470, 2009.

[42] A.-K. Bock, E. Rodriguez-Cerezo, B. Hüsing, B. Bührlen, and M. Nusser, "Human tissue-engineered products: potential socio-economic impacts of a new European regulatory framework for authorisation, supervision and vigilance," Tech. Rep. EUR 21838 EN, Joint Research Center, Karlsruhe, Germany, 2005.

[43] Knowledge Enterprises, The Worldwide Orthopedic Market2005-2006, Knowledge Enterprises, Chagrin Falls, Ohio, USA, 2006. 
[44] C. A. Kirker-Head, "Potential applications and delivery strategies for bone morphogenetic proteins," Advanced Drug Delivery Reviews, vol. 43, no. 1, pp. 65-92, 2000.

[45] L. Grgurevic, B. Macek, M. Mercep et al., "Bone morphogenetic protein (BMP)1-3 enhances bone repair," Biochemical and Biophysical Research Communications, vol. 408, no. 1, pp. 25-31, 2011.

[46] N. Sykaras and L. A. Opperman, "Bone morphogenetic proteins (BMPs): how do they function and what can they offer the clinician?" Journal of Oral Science, vol. 45, no. 2, pp. 57-73, 2003.

[47] J. W. Lee, K. S. Kang, S. H. Lee, J.-Y. Kim, B.-K. Lee, and D.-W. Cho, "Bone regeneration using a microstereolithographyproduced customized poly(propylene fumarate)/diethyl fumarate photopolymer 3D scaffold incorporating BMP-2 loaded PLGA microspheres," Biomaterials, vol. 32, no. 3, pp. 744-752, 2011.

[48] Z. Chen, D. Li, B. Lu, Y. Tang, M. Sun, and S. Xu, "Fabrication of osteo-structure analogous scaffolds via fused deposition modeling," Scripta Materialia, vol. 52, no. 2, pp. 157-161, 2005.

[49] J.-Y. Lee, J.-E. Choo, Y.-S. Choi et al., "Osteoblastic differentiation of human bone marrow stromal cells in self-assembled BMP-2 receptor-binding peptide-amphiphiles," Biomaterials, vol. 30, no. 21, pp. 3532-3541, 2009.

[50] S. C.-N. Chang, H. Chuang, Y.-R. Chen et al., "Cranial repair using BMP-2 gene engineered bone marrow stromal cells," Journal of Surgical Research, vol. 119, no. 1, pp. 85-91, 2004.

[51] Y. Bai, G. Yin, Z. Huang et al., "Localized delivery of growth factors for angiogenesis and bone formation in tissue engineering," International Immunopharmacology, vol. 16, no. 2, pp. 214-223, 2013.

[52] V. I. Sikavitsas, J. S. Temenoff, and A. G. Mikos, "Biomaterials and bone mechanotransduction," Biomaterials, vol. 22, no. 19, pp. 2581-2593, 2001.

[53] T. L. McCarthy, M. Centrella, and E. Canalis, "Insulin-like growth factor (IGF) and bone," Connective Tissue Research, vol. 20, no. 1-4, pp. 277-282, 1989.

[54] D. Kaigler, G. Avila, L. Wisner-Lynch et al., "Platelet-derived growth factor applications in periodontal and peri-implant bone regeneration," Expert Opinion on Biological Therapy, vol. 11, no. 3, pp. 375-385, 2011.

[55] M. Bosetti, F. Boccafoschi, M. Leigheb, and M. F. Cannas, "Effect of different growth factors on human osteoblasts activities: a possible application in bone regeneration for tissue engineering," Biomolecular Engineering, vol. 24, no. 6, pp. 613-618, 2007.

[56] Y. Ikada, "Challenges in tissue engineering," Interface, vol. 3, no. 10, pp. 589-601, 2006.

[57] T. Adachi, Y. Osako, M. Tanaka, M. Hojo, and S. J. Hollister, "Framework for optimal design of porous scaffold microstructure by computational simulation of bone regeneration," Biomaterials, vol. 27, no. 21, pp. 3964-3972, 2006.

[58] Y. Chen, S. Zhou, and Q. Li, "Microstructure design of biodegradable scaffold and its effect on tissue regeneration," Biomaterials, vol. 32, no. 22, pp. 5003-5014, 2011.

[59] S. J. Hollister, R. D. Maddox, and J. M. Taboas, "Optimal design and fabrication of scaffolds to mimic tissue properties and satisfy biological constraints," Biomaterials, vol. 23, no. 20, pp. 4095-4103, 2002.

[60] S. J. Hollister, "Porous scaffold design for tissue engineering," Nature Materials, vol. 4, no. 7, pp. 518-524, 2005.

[61] M. Schicker, H. Seitz, I. Drosse, S. Seitz, and W. Mutschler, "Biomaterials as scaffold for bone tissue engineering," European Journal of Trauma, vol. 32, no. 2, pp. 114-124, 2006.
[62] A. W. Lloyd, "Interfacial bioengineering to enhance surface biocompatibility," Medical Device Technology, vol. 13, no. 1, pp. 18-21, 2002.

[63] D. P. Byrne, D. Lacroix, J. A. Planell, D. J. Kelly, and P. J. Prendergast, "Simulation of tissue differentiation in a scaffold as a function of porosity, Young's modulus and dissolution rate: application of mechanobiological models in tissue engineering," Biomaterials, vol. 28, no. 36, pp. 5544-5554, 2007.

[64] A. Kolk, J. Handschel, W. Drescher et al., "Current trends and future perspectives of bone substitute materials-from space holders to innovative biomaterials," Journal of Cranio-Maxillofacial Surgery, vol. 40, no. 8, pp. 706-718, 2012.

[65] S. Rajagopalan and R. A. Robb, "Schwarz meets Schwann: design and fabrication of biomorphic and durataxic tissue engineering scaffolds," Medical Image Analysis, vol. 10, no. 5, pp. 693-712, 2006.

[66] M. Vert, "Polymeric biomaterials: strategies of the past vs. strategies of the future," Progress in Polymer Science, vol. 32, no. 8-9, pp. 755-761, 2007.

[67] S. M. Giannitelli, D. Accoto, M. Trombetta, and A. Rainer, "Current trends in the design of scaffolds for computer-aided tissue engineering," Acta Biomaterialia, vol. 10, no. 2, pp. 580594, 2014.

[68] C. Estrada, A. C. Paz, and L. E. López, "Ingeniería de tejido óseo: consideraciones básicas," Revista EIA, vol. 5, pp. 93-100, 2006.

[69] S. Bose, M. Roy, and A. Bandyopadhyay, "Recent advances in bone tissue engineering scaffolds," Trends in Biotechnology, vol. 30, no. 10, pp. 546-554, 2012.

[70] S. Ramakrishna, J. Mayer, E. Wintermantel, and K. W. Leong, "Biomedical applications of polymer-composite materials: a review," Composites Science and Technology, vol. 61, no. 9, pp. 1189-1224, 2001.

[71] M. Vert, Y. Doi, K.-H. Hellwich et al., “Terminology for biorelated polymers and applications (IUPAC recommendations 2012)," Pure and Applied Chemistry, vol. 84, no. 2, pp. 377-410, 2012.

[72] F. Edalat, H. Bae, S. Manoucheri, J. M. Cha, and A. Khademhosseini, "Engineering approaches toward deconstructing and controlling the stem cell environment," Annals of Biomedical Engineering, vol. 40, no. 6, pp. 1301-1315, 2012.

[73] T. Garg, O. Singh, S. Arora, and R. Murthy, "Scaffold: a novel carrier for cell and drug delivery," Critical Reviews in Therapeutic Drug Carrier Systems, vol. 29, no. 1, pp. 1-63, 2012.

[74] D. Logeart-Avramoglou, F. Anagnostou, R. Bizios, and H. Petite, "Engineering bone: challenges and obstacles," Journal of Cellular and Molecular Medicine, vol. 9, no. 1, pp. 72-84, 2005.

[75] J. M. Taboas, R. D. Maddox, P. H. Krebsbach, and S. J. Hollister, "Indirect solid free form fabrication of local and global porous, biomimetic and composite 3D polymer-ceramic scaffolds," Biomaterials, vol. 24, no. 1, pp. 181-194, 2003.

[76] V. Karageorgiou and D. Kaplan, "Porosity of 3D biomaterial scaffolds and osteogenesis," Biomaterials, vol. 26, no. 27, pp. 5474-5491, 2005.

[77] W. Sun, B. Starly, J. Nam, and A. Darling, "Bio-CAD modeling and its applications in computer-aided tissue engineering," Computer-Aided Design, vol. 37, no. 11, pp. 1097-1114, 2005.

[78] Y. Chen, S. Zhou, and Q. Li, "Mathematical modeling of degradation for bulk-erosive polymers: applications in tissue engineering scaffolds and drug delivery systems," Acta Biomaterialia, vol. 7, no. 3, pp. 1140-1149, 2011. 
[79] R. Voronov, S. VanGordon, V. I. Sikavitsas, and D. V. Papavassiliou, "Computational modeling of flow-induced shear stresses within 3D salt-leached porous scaffolds imaged via micro-CT," Journal of Biomechanics, vol. 43, no. 7, pp. 1279-1286, 2010.

[80] W. A. Comisar, N. H. Kazmers, D. J. Mooney, and J. J. Linderman, "Engineering RGD nanopatterned hydrogels to control preosteoblast behavior: a combined computational and experimental approach," Biomaterials, vol. 28, no. 30, pp. 44094417, 2007.

[81] V. J. Chen, L. A. Smith, and P. X. Ma, "Bone regeneration on computer-designed nano-fibrous scaffolds," Biomaterials, vol. 27, no. 21, pp. 3973-3979, 2006.

[82] S. Zhang, D. M. Marini, W. Hwang, and S. Santoso, "Design of nanostructured biological materials through self-assembly of peptides and proteins," Current Opinion in Chemical Biology, vol. 6 , no. 6, pp. 865-871, 2002.

[83] Y. Kuboki, H. Takita, D. Kobayashi et al., "BMP-induced osteogenesis on the surface of hydroxyapatite with geometrically feasible and nonfeasible structures: topology of osteogenesis," Journal of Biomedical Materials Research, vol. 39, no. 2, pp. 190199, 1998.

[84] M. Fröhlich, W. L. Grayson, L. Q. Wan, D. Marolt, M. Drobnic, and G. Vunjak-Novakovic, "Tissue engineered bone grafts: biological requirements, tissue culture and clinical relevance," Current Stem Cell Research \& Therapy, vol. 3, no. 4, pp. 254-264, 2008.

[85] S. F. Hulbert, F. A. Young, R. S. Mathews, J. J. Klawitter, C. D. Talbert, and F. H. Stelling, "Potential of ceramic materials as permanently implantable skeletal prostheses," Journal of Biomedical Materials Research, vol. 4, no. 3, pp. 433-456, 1970.

[86] K. Whang, K. E. Healy, D. R. Elenz, and et al, "Engineering bone regeneration with bioabsorbable scaffolds with novel microarchitecture," Tissue Engineering, vol. 5, no. 1, pp. 35-51, 1999.

[87] C. N. Cornell, "Osteoconductive materials and their role as substitutes for autogenous bone grafts," Orthopedic Clinics of North America, vol. 30, no. 4, pp. 591-598, 1999.

[88] S. J. Hollister, C. Y. Lin, E. Saito et al., "Engineering craniofacial scaffolds," Orthodontics and Craniofacial Research, vol. 8, no. 3, pp. 162-173, 2005.

[89] M. Bohner, Y. Loosli, G. Baroud, and D. Lacroix, "Deciphering the link between architecture and biological response of a bone graft substitute," Acta Biomaterialia, vol. 7, no. 2, pp. 478-484, 2011.

[90] S. Bose, S. Vahabzadeh, and A. Bandyopadhyay, "Bone tissue engineering using 3D printing," Materials Today, vol. 16, no. 12, pp. 496-504, 2013.

[91] X. Li, D. Li, B. Lu, L. Wang, and Z. Wang, "Fabrication and evaluation of calcium phosphate cement scaffold with controlled internal channel architecture and complex shape," Proceedings of the Institution of Mechanical Engineers, Part H: Journal of Engineering in Medicine, vol. 221, no. 8, pp. 951-958, 2007.

[92] L. Liulan, H. Qingxi, H. Xianxu, and X. Gaochun, "Design and fabrication of bone tissue engineering scaffolds via rapid prototyping and CAD," Journal of Rare Earths, vol. 25, no. 2, pp. 379-383, 2007.

[93] J. Guo, Q. X. Hu, Y. Yao, Q. Lu, Y. W. Yu, and Y. Qian, “A pore network model based method for tissue engineering scaffold design," in Proceedings of the International Conference on Biomedical Engineering and Computer Science (ICBECS '10), pp. 1-4, April 2010.
[94] Q. Lian, D.-C. Li, Y.-P. Tang, and Y.-R. Zhang, "Computer modeling approach for a novel internal architecture of artificial bone," Computer-Aided Design, vol. 38, no. 5, pp. 507-514, 2006.

[95] L. Jongpaiboonkit, J. W. Halloran, and S. J. Hollister, "Internal structure evaluation of three-dimensional calcium phosphate bone scaffolds: a micro-computed tomographic study," Journal of the American Ceramic Society, vol. 89, no. 10, pp. 3176-3181, 2006.

[96] A. Armillotta and R. Pelzer, "Modeling of porous structures for rapid prototyping of tissue engineering scaffolds," International Journal of Advanced Manufacturing Technology, vol. 39, no. 5-6, pp. 501-511, 2008.

[97] C. Zhongzhong, F. Xilan, and J. Zhiqiang, "Structural design and optimization of interior scaffolds in artificial bone," in Proceedings of the 1st International Conference on Bioinformatics and Biomedical Engineering (CBBE '07), pp. 330-333, July 2007.

[98] C. M. Cheah, C. K. Chua, K. F. Leong, and S. W. Chua, "Development of a tissue engineering scaffold structure library for rapid prototyping. Part 1: investigation and classification," International Journal of Advanced Manufacturing Technology, vol. 21, no. 4, pp. 291-301, 2003.

[99] A. L. Olivares, È. Marsal, J. A. Planell, and D. Lacroix, "Finite element study of scaffold architecture design and culture conditions for tissue engineering," Biomaterials, vol. 30, no. 30, pp. 6142-6149, 2009.

[100] F. P. W. Melchels, A. M. C. Barradas, C. A. van Blitterswijk, J. de Boer, J. Feijen, and D. W. Grijpma, "Effects of the architecture of tissue engineering scaffolds on cell seeding and culturing," Acta Biomaterialia, vol. 6, no. 11, pp. 4208-4217, 2010.

[101] F. P. W. Melchels, K. Bertoldi, R. Gabbrielli, A. H. Velders, J. Feijen, and D. W. Grijpma, "Mathematically defined tissue engineering scaffold architectures prepared by stereolithography," Biomaterials, vol. 31, no. 27, pp. 6909-6916, 2010.

[102] S. C. Kapfer, S. T. Hyde, K. Mecke, C. H. Arns, and G. E. Schröder-Turk, "Minimal surface scaffold designs for tissue engineering," Biomaterials, vol. 32, no. 29, pp. 6875-6882, 2011.

[103] D. Yoo, "New paradigms in internal architecture design and freeform fabrication of tissue engineering porous scaffolds," Medical Engineering and Physics, vol. 34, no. 6, pp. 762-776, 2012.

[104] A. Pasko, O. Fryazinov, T. Vilbrandt, P.-A. Fayolle, and V. Adzhiev, "Procedural function-based modelling of volumetric microstructures," Graphical Models, vol. 73, no. 5, pp. 165-181, 2011.

[105] P. Pandithevan and G. Saravana Kumar, "Personalised bone tissue engineering scaffold with controlled architecture using fractal tool paths in layered manufacturing," Virtual and Physical Prototyping, vol. 4, no. 3, pp. 165-180, 2009.

[106] B. S. Bucklen, W. A. Wettergreen, E. Yuksel, and M. A. K. Liebschner, "Bone-derived CAD library for assembly of scaffolds in computer-aided tissue engineering," Virtual and Physical Prototyping, vol. 3, no. 1, pp. 13-23, 2008.

[107] G. H. van Lenthe, H. Hagenmüller, M. Bohner, S. J. Hollister, L. Meinel, and R. Müller, "Nondestructive micro-computed tomography for biological imaging and quantification of scaffold-bone interaction in vivo," Biomaterials, vol. 28, no. 15, pp. 2479-2490, 2007.

[108] Z. Hu, B. Notarberardino, M. Baker et al., "On modeling bioscaffolds: structural and fluid transport characterization based on 3-D imaging data," Tsinghua Science and Technology, vol. 14, supplement 1, pp. 20-23, 2009. 
[109] X. Y. Kou and S. T. Tan, "A simple and effective geometric representation for irregular porous structure modeling," Computer Aided Design, vol. 42, no. 10, pp. 930-941, 2010.

[110] Z. Fang, B. Starly, and W. Sun, "Computer-aided characterization for effective mechanical properties of porous tissue scaffolds," CAD Computer Aided Design, vol. 37, no. 1, pp. 6572, 2005.

[111] R. J. Shipley, G. W. Jones, R. J. Dyson et al., "Design criteria for a printed tissue engineering construct: a mathematical homogenization approach," Journal of Theoretical Biology, vol. 259, no. 3, pp. 489-502, 2009.

[112] S. Cowin, "Remarks on optimization and the prediction of bone adaptation to altered loading," New York Cent. Biomed. Eng., 2003.

[113] C. Y. Lin, N. Kikuchi, and S. J. Hollister, "A novel method for biomaterial scaffold internal architecture design to match bone elastic properties with desired porosity," Journal of Biomechanics, vol. 37, no. 5, pp. 623-636, 2004.

[114] S. J. Hollister and C. Y. Lin, "Computational design of tissue engineering scaffolds," Computer Methods in Applied Mechanics and Engineering, vol. 196, no. 31-32, pp. 2991-2998, 2007.

[115] H. D. A. Almeida and P. J. da Silva Bártolo, "Virtual topological optimisation of scaffolds for rapid prototyping," Medical Engineering and Physics, vol. 32, no. 7, pp. 775-782, 2010.

[116] D. F. Williams, "On the nature of biomaterials," Biomaterials, vol. 30, no. 30, pp. 5897-5909, 2009.

[117] M. M. Stevens, "Biomaterials for bone tissue engineering," Materials Today, vol. 11, no. 5, pp. 18-25, 2008.

[118] A. S. AlGhamdi, O. Shibly, and S. G. Ciancio, "Osseous grafting part II: xenografts and alloplasts for periodontal regenerationa literature review," Journal of the International Academy of Periodontology, vol. 12, no. 2, pp. 39-44, 2010.

[119] A. Oryan, S. Alidadi, A. Moshiri, and N. Maffulli, "Bone regenerative medicine: classic options, novel strategies, and future directions," Journal of Orthopaedic Surgery and Research, vol. 9, no. 1, article 18, 2014.

[120] C. Verwilghen, M. Chkir, S. Rio, A. Nzihou, P. Sharrock, and G. Depelsenaire, "Convenient conversion of calcium carbonate to hydroxyapatite at ambient pressure," Materials Science and Engineering C, vol. 29, no. 3, pp. 771-773, 2009.

[121] T. Guda, M. Appleford, S. Oh, and J. L. Ong, "A cellular perspective to bioceramic scaffolds for bone tissue engineering: the state of the art," Current Topics in Medicinal Chemistry, vol. 8, no. 4, pp. 290-299, 2008.

[122] R. Z. LeGeros, "Properties of osteoconductive biomaterials: calcium phosphates," Clinical Orthopaedics and Related Research, no. 395, pp. 81-98, 2002.

[123] S. Samavedi, A. R. Whittington, and A. S. Goldstein, "Calcium phosphate ceramics in bone tissue engineering: a review of properties and their influence on cell behavior," Acta Biomaterialia, vol. 9, no. 9, pp. 8037-8045, 2013.

[124] J. R. Porter, T. T. Ruckh, and K. C. Popat, "Bone tissue engineering: a review in bone biomimetics and drug delivery strategies," Biotechnology Progress, vol. 25, no. 6, pp. 1539-1560, 2009.

[125] L. Tzvetanov, S. Nikolaeva, I. Michailov, and P. Tivchev, "Bone and ceramic interaction in the bone union process," Ultrastructural Pathology, vol. 26, no. 3, pp. 171-175, 2002.

[126] A. Ravaglioli, A. Krajewski, G. Baldi, F. Tateo, L. Peruzzo, and A. Piancastelli, "Glass-ceramic scaffolds for tissue engineering," Advances in Applied Ceramics, vol. 107, no. 5, pp. 268-273, 2008.
[127] L. L. Hench, N. Roki, and M. B. Fenn, "Bioactive glasses: importance of structure and properties in bone regeneration," Journal of Molecular Structure, vol. 1073, pp. 24-30, 2014.

[128] J. R. Jones, "Review of bioactive glass: From Hench to hybrids," Acta Biomaterialia, vol. 9, no. 1, pp. 4457-4486, 2013.

[129] J. F. Mano, G. A. Silva, H. S. Azevedo et al., "Natural origin biodegradable systems in tissue engineering and regenerative medicine: present status and some moving trends," Journal of the Royal Society Interface, vol. 4, no. 17, pp. 999-1030, 2007.

[130] B. Dhandayuthapani, Y. Yoshida, T. Maekawa, and D. S. Kumar, "Polymeric scaffolds in tissue engineering application: a review," International Journal of Polymer Science, vol. 2011, Article ID 290602, 19 pages, 2011.

[131] J. C. Middleton and A. J. Tipton, "Synthetic biodegradable polymers as orthopedic devices," Biomaterials, vol. 21, no. 23, pp. 2335-2346, 2000.

[132] L. Yang, K. O. van der Werf, C. F. C. Fitié, M. L. Bennink, P. J. Dijkstra, and J. Feijen, "Mechanical properties of native and cross-linked type I collagen fibrils," Biophysical Journal, vol. 94, no. 6, pp. 2204-2211, 2008.

[133] M. Okada, "Chemical syntheses of biodegradable polymers," Progress in Polymer Science, vol. 27, no. 1, pp. 87-133, 2002.

[134] L. S. Nair and C. T. Laurencin, "Biodegradable polymers as biomaterials," Progress in Polymer Science (Oxford), vol. 32, no. 8-9, pp. 762-798, 2007.

[135] A. Göpferich, "Polymer bulk erosion," Macromolecules, vol. 30, no. 9, pp. 2598-2604, 1997.

[136] E. J. Frazza and E. E. Schmitt, “A new absorbable suture," Journal of Biomedical Materials Research, vol. 5, no. 2, pp. 43-58, 1971.

[137] P. B. Maurus and C. C. Kaeding, "Bioabsorbable implant material review," Operative Techniques in Sports Medicine, vol. 12, no. 3, pp. 158-160, 2004.

[138] G.-X. Chen, H.-S. Kim, E.-S. Kim, and J.-S. Yoon, "Synthesis of high-molecular-weight poly(L-lactic acid) through the direct condensation polymerization of 1-lactic acid in bulk state," European Polymer Journal, vol. 42, no. 2, pp. 468-472, 2006.

[139] M. Savioli Lopes, A. L. Jardini, and R. Maciel Filho, "Poly (lactic acid) production for tissue engineering applications," in Proceedings of the 20th International Congress of Chemical and Process Engineering (CHISA '12), pp. 1402-1413, August 2012.

[140] G. Perego, G. D. Cella, and C. Bastioli, "Effect of molecular weight and crystallinity on poly(lactic acid) mechanical properties," Journal of Applied Polymer Science, vol. 59, no. 1, pp. 37-43, 1996.

[141] S. Wu, X. Liu, K. W. K. Yeung, C. Liu, and X. Yang, "Biomimetic porous scaffolds for bone tissue engineering," Materials Science and Engineering R: Reports, vol. 80, no. 1, pp. 1-36, 2014.

[142] Q. Chen, C. Zhu, and G. A. Thouas, "Progress and challenges in biomaterials used for bone tissue engineering: bioactive glasses and elastomeric composites," Progress in Biomaterials, vol. 1, no. 1, article 2, 2012.

[143] D. A. Wahl and J. T. Czernuszka, "Collagen-hydroxyapatite composites for hard tissue repair," European Cells and Materials, vol. 11, pp. 43-56, 2006.

[144] J. E. Bergsma, F. R. Rozema, R. R. M. Bos, G. Boering, W. C. de Bruijn, and A. J. Pennings, "In vivo degradation and biocompatibility study of in vitro pre-degraded as-polymerized polyactide particles," Biomaterials, vol. 16, no. 4, pp. 267-274, 1995.

[145] S. Jacobsen and H. G. Fritz, "Plasticizing polylactide-the effect of different plasticizers on the mechanical properties," Polymer Engineering and Science, vol. 39, no. 7, pp. 1303-1310, 1999. 
[146] P. Gunatillake, R. Mayadunne, and R. Adhikari, "Recent developments in biodegradable synthetic polymers," Biotechnology Annual Review, vol. 12, pp. 301-347, 2006.

[147] H. Chim, D. W. Hutmacher, A. M. Chou et al., "A comparative analysis of scaffold material modifications for load-bearing applications in bone tissue engineering," International Journal of Oral and Maxillofacial Surgery, vol. 35, no. 10, pp. 928-934, 2006.

[148] C. Du, F. Z. Cui, Q. L. Feng, X. D. Zhu, and K. de Groot, “Tissue response to nano-hydroxyapatite/collagen composite implants in marrow cavity," Journal of Biomedical Materials Research, vol. 42, no. 4, pp. 540-548, 1998.

[149] W. Zhang, S. S. Liao, and F. Z. Cui, "Hierarchical self-assembly of nano-fibrils in mineralized collagen," Chemistry of Materials, vol. 15, no. 16, pp. 3221-3226, 2003.

[150] P. X. Ma and J. Elisseeff, Scaffolding in Tissue Engineering, CRC Press, New York, NY, USA, 2006.

[151] J. L. Brown, S. G. Kumbar, and C. T. Laurencin, "Bone tissue engineering," in Biomaterials Science, B. Ratner, A. S. Hoffman, F. J. Schoen, and J. E. Lemons, Eds., pp. 1194-1214, Elsevier, Oxford, UK, 3rd edition, 2013.

[152] D. P. Pioletti, "Biomechanical considerations can serve as design rules in the development of bone tissue engineering scaffold," Computer Methods in Biomechanics and Biomedical Engineering, vol. 12, supplement 1, pp. 17-18, 2009.

[153] J. C. Y. Dunn, W.-Y. Chan, V. Cristini et al., "Analysis of cell growth in three-dimensional scaffolds," Tissue Engineering, vol. 12, no. 4, pp. 705-716, 2006.

[154] D. J. Wilson, J. R. King, and H. M. Byrne, "Modelling scaffold occupation by a growing, nutrient-rich tissue," Mathematical Models and Methods in Applied Sciences, vol. 17, pp. 1721-1750, 2007.

[155] D. Jeong, A. Yun, and J. Kim, "Mathematical model and numerical simulation of the cell growth in scaffolds," Biomechanics and Modeling in Mechanobiology, vol. 11, no. 5, pp. 677-688, 2012.

[156] J. A. Sanz-Herrera, J. M. Garcia-Aznar, and M. Doblare, "A mathematical model for bone tissue regeneration inside a specific type of scaffold," Biomechanics and Modeling in Mechanobiology, vol. 7, no. 5, pp. 355-366, 2008.

[157] F. Galbusera, L. Bertolazzi, R. Balossino, and G. Dubini, "Combined computational study of mechanical behaviour and drug delivery from a porous, hydroxyapatite-based bone graft," Biomechanics and Modeling in Mechanobiology, vol. 8, no. 3, pp. 209-216, 2009.

[158] X. Liu and G. L. Niebur, "Bone ingrowth into a porous coated implant predicted by a mechano-regulatory tissue differentiation algorithm," Biomechanics and Modeling in Mechanobiology, vol. 7, no. 4, pp. 335-344, 2008.

[159] C. A. Narváez-Tovar and D. A. Garzón-Alvarado, "Computational modeling of the mechanical modulation of the growth plate by sustained loading," Theoretical Biology and Medical Modelling, vol. 9, no. 1, article 41, 2012.

[160] X. Han and J. Pan, "A model for simultaneous crystallisation and biodegradation of biodegradable polymers," Biomaterials, vol. 30, no. 3, pp. 423-430, 2009.

[161] J. A. Sanz-Herrera and A. R. Boccaccini, "Modelling bioactivity and degradation of bioactive glass based tissue engineering scaffolds," International Journal of Solids and Structures, vol. 48, no. 2, pp. 257-268, 2011.

[162] M. P. Ginebra, T. Traykova, and J. A. Planell, "Calcium phosphate cements as bone drug delivery systems: a review," Journal of Controlled Release, vol. 113, no. 2, pp. 102-110, 2006.
[163] M. Ginebra, F. Gil, and J. Planell, "Acrylic bone cements," in Integrated Biomaterials Science, R. Barbucci, Ed., pp. 569-588, Kluwer Academy/Plenum, 1st edition, 2002.

[164] S. M. Kenny and M. Buggy, "Bone cements and fillers: a review," Journal of Materials Science: Materials in Medicine, vol. 14, no. 11, pp. 923-938, 2003.

[165] R. Huiskes and M. C. H. van der Meulen, "Why mechanobiology?” Journal of Biomechanics, vol. 35, no. 4, pp. 401-414, 2002.

[166] D. J. Kelly and P. J. Prendergast, "Mechano-regulation of stem cell differentiation and tissue regeneration in osteochondral defects," Journal of Biomechanics, vol. 38, no. 7, pp. 1413-1422, 2005.

[167] R. G. Bacabac and M. G. Mullender, "Mechanobiology of bone tissue," Pathologie Biologie, vol. 53, no. 10, pp. 576-580, 2005.

[168] R. P. Gehron, “The biochemistry of bone," Endocrinology Metabolism Clinics of North America, vol. 18, no. 4, p. 858, 1989.

[169] H. Cölfen, "Biomineralization: a crystal-clear view," Nature Materials, vol. 9, no. 12, pp. 960-961, 2010.

[170] M. J. Olszta, X. Cheng, S. S. Jee et al., "Bone structure and formation: a new perspective," Materials Science and Engineering R: Reports, vol. 58, no. 3-5, pp. 77-116, 2007.

[171] L. G. Raisz, "Bone biology: bone structure and remodeling," Bone Disease of Organ Transplantation, pp. 31-45, 2005.

[172] L. M. McNamara and P. J. Prendergast, "Bone remodelling algorithms incorporating both strain and microdamage stimuli," Journal of Biomechanics, vol. 40, no. 6, pp. 1381-1391, 2007.

[173] R. Baron, "Anatomy and ultrastructure of bone-histogenesis, growth and remodeling," in Diseases of Bone and Mineral Metabolism, 2006.

[174] C. C. Ko, M. J. Somerman, and K. A. An, "Motion and bone regeneration," in Engineering of Functional Skeletal Tissues, F. Bronner, M. Farach, and A. Mikos, Eds., pp. 110-127, Springer, Berlin, Germany, 2007.

[175] L. Geris, J. vander Sloten, and H. van Oosterwyck, "Mathematical modeling of bone regeneration including the angiogenic process," Journal of Biomechanics, vol. 39, supplement 1, pp. S411-S412, 2006.

[176] P. V. Giannoudis, T. A. Einhorn, and D. Marsh, "Fracture healing: the diamond concept," Injury, vol. 38, supplement 4, pp. S3-S6, 2007.

[177] N. A. Sims and J. H. Gooi, "Bone remodeling: multiple cellular interactions required for coupling of bone formation and resorption," Seminars in Cell \& Developmental Biology, vol. 19, no. 5, pp. 444-451, 2008.

[178] A. M. Parfitt, "Modeling and remodeling: how bone cells work together," Vitamin D, vol. 1, pp. 497-513, 2005.

[179] P. Pivonka, J. Zimak, D. W. Smith et al., "Model structure and control of bone remodeling: a theoretical study," Bone, vol. 43, no. 2, pp. 249-263, 2008.

[180] G. R. Mundy, "Cellular and molecular regulation of bone turnover," Bone, vol. 24, supplement 5, pp. 35S-38S, 1999.

[181] H. Tsurukami, "Disorder of bone quality in Paget's disease," Clinical Calcium, vol. 15, no. 6, pp. 1000-1006, 2005.

[182] S. Nomura and T. Takano-Yamamoto, "Molecular events caused by mechanical stress in bone," Matrix Biology, vol. 19, no. 2, pp. 91-96, 2000.

[183] T. Adachi, Y. Aonuma, S.-I. Ito et al., "Osteocyte calcium signaling response to bone matrix deformation," Journal of Biomechanics, vol. 42, no. 15, pp. 2507-2512, 2009. 
[184] V. Lemaire, F. L. Tobin, L. D. Greller, C. R. Cho, and L. J. Suva, "Modeling the interactions between osteoblast and osteoclast activities in bone remodeling," Journal of Theoretical Biology, vol. 229, no. 3, pp. 293-309, 2004.

[185] C. H. Turner, "Functional determinants of bone structure: beyond Wolff's law of bone transformation," Bone, vol. 13, no. 6, pp. 403-409, 1992.

[186] J. G. Skedros and S. L. Baucom, "Mathematical analysis of trabecular 'trajectories' in apparent trajectorial structures: the unfortunate historical emphasis on the human proximal femur," Journal of Theoretical Biology, vol. 244, no. 1, pp. 15-45, 2007.

[187] R. E. Guldberg, C. S. Gemmiti, Y. Kolambkar, and B. Porter, "Physical stress as a factor in tissue growth and remodeling," in Principles of Regenerative Medicine, pp. 512-535, Academic Press, San Diego, Calif, USA, 2008.

[188] F. Forriol, "Bone response to mechanical demand under physiological conditions," Revista Española de Cirugía Ortopédica y Traumatología, vol. 45, no. 3, pp. 258-265, 2001.

[189] A. Boccaccio, A. Ballini, C. Pappalettere, D. Tullo, S. Cantore, and A. Desiate, "Finite element method (FEM), mechanobiology and biomimetic scaffolds in bone tissue engineering," International Journal of Biological Sciences, vol. 7, no. 1, pp. 112132, 2011.

[190] M. C. H. Van der Meulen and R. Huiskes, "Why mechanobiology?” Journal of Biomechanics, vol. 35, no. 4, pp. 401-414, 2002.

[191] D. E. Ingber, "Cellular mechanotransduction: putting all the pieces together again," The FASEB Journal, vol. 20, no. 7, pp. 811827,2006

[192] H. Isaksson, W. Wilson, C. C. van Donkelaar, R. Huiskes, and K. Ito, "Comparison of biophysical stimuli for mechano-regulation of tissue differentiation during fracture healing," Journal of Biomechanics, vol. 39, no. 8, pp. 1507-1516, 2006.

[193] S. Weinbaum, S. C. Cowin, and Y. Zeng, "A model for the excitation of osteocytes by mechanical loading-induced bone fluid shear stresses," Journal of Biomechanics, vol. 27, no. 3, pp. 339-360, 1994.

[194] J. P. Stains and R. Civitelli, "Cell-to-cell interactions in bone," Biochemical and Biophysical Research Communications, vol. 328, no. 3, pp. 721-727, 2005.

[195] C. P. Huang, X. M. Chen, and Z. Q. Chen, "Osteocyte: the impresario in the electrical stimulation for bone fracture healing," Medical Hypotheses, vol. 70, no. 2, pp. 287-290, 2008.

[196] E. H. Burger and J. Klein-Nulend, "Mechanotransduction in bone-role of the lacuno-canalicular network," FASEB Journal, vol. 13, no. 8, pp. S101-S112, 1999.

[197] H. Frost, The Laws of Bone Structure, Charles Thomas, Springfield, Ill, USA, 1964.

[198] H. M. Frost, "Functional determinants of bone structure: beyond Wolff's law of bone transformation," The Angle Orthodontist, vol. 64, no. 3, pp. 175-188, 1994.

[199] H. M. Frost, "Vital biomechanics: proposed general concepts for skeletal adaptations to mechanical usage," Calcified Tissue International, vol. 42, no. 3, pp. 145-156, 1988.

[200] D. R. Carter, G. S. Beaupré, N. J. Giori, and J. A. Helms, "Mechanobiology of skeletal regeneration," Clinical Orthopaedics and Related Research, no. 355, supplement, pp. S41-S55, 1998.

[201] L. E. Claes and C. A. Heigele, "Magnitudes of local stress and strain along bony surfaces predict the course and type of fracture healing," Journal of Biomechanics, vol. 32, no. 3, pp. 255$266,1999$.
[202] D. Lacroix and P. J. Prendergast, "A mechano-regulation model for tissue differentiation during fracture healing: analysis of gap size and loading," Journal of Biomechanics, vol. 35, no. 9, pp. 1163-1171, 2002.

[203] R. Huiskes, H. Weinans, H. J. Grootenboer, M. Dalstra, B. Fudala, and T. J. Slooff, "Adaptive bone-remodeling theory applied to prosthetic-design analysis," Journal of Biomechanics, vol. 20, no. 11-12, pp. 1135-1150, 1987.

[204] F. Pauwels, "A new theory on the influence of mechanical stimuli on the differentiation of supporting tissue. The tenth contribution to the functional anatomy and causal morphology of the supporting structure," Zeitschrift fur Anatomie und Entwicklungsgeschichte, vol. 121, pp. 478-515, 1960.

[205] P. J. Prendergast, "Finite element models in tissue mechanics and orthopaedic implant design," Clinical Biomechanics, vol. 12, no. 6, pp. 343-366, 1997.

[206] D. P. Fyhrie and D. R. Carter, "A unifying principle relating stress to trabecular bone morphology," Journal of Orthopaedic Research, vol. 4, no. 3, pp. 304-317, 1986.

[207] B. G. Sengers, M. Taylor, C. P. Please, and R. O. C. Oreffo, "Computational modelling of cell spreading and tissue regeneration in porous scaffolds," Biomaterials, vol. 28, no. 10, pp. 1926-1940, 2007.

[208] M. Kassem, L. Ankersen, E. F. Eriksen, B. F. C. Clark, and S. I. S. Rattan, "Demonstration of cellular aging and senescence in serially passaged long-term cultures of human trabecular osteoblasts," Osteoporosis International, vol. 7, no. 6, pp. 514-524, 1997.

[209] M. A. Pérez and P. J. Prendergast, "Random-walk models of cell dispersal included in mechanobiological simulations of tissue differentiation," Journal of Biomechanics, vol. 40, no. 10, pp. 2244-2253, 2007.

[210] A. Roshan-Ghias, A. Vogel, L. Rakotomanana, and D. P. Pioletti, "Prediction of spatio-temporal bone formation in scaffold by diffusion equation," Biomaterials, vol. 32, no. 29, pp. 7006-7012, 2011.

[211] C. R. Jacobs, J. C. Simo, G. S. Beaupré, and D. R. Cartert, "Adaptive bone remodeling incorporating simultaneous density and anisotropy considerations," Journal of Biomechanics, vol. 30, no. 6, pp. 603-613, 1997.

[212] D. R. Carter, T. E. Orr, and D. P. Fyhrie, "Relationships between loading history and femoral cancellous bone architecture," Journal of Biomechanics, vol. 22, no. 3, pp. 231-244, 1989.

[213] H. Weinans, R. Huiskes, and H. J. Grootenboer, "The behavior of adaptive bone-remodeling simulation models," Journal of Biomechanics, vol. 25, no. 12, pp. 1425-1441, 1992.

[214] M. G. Mullender and R. Huiskes, "Osteocytes and bone lining cells: which are the best candidates for mechano-sensors in cancellous bone?" Bone, vol. 20, no. 6, pp. 527-532, 1997.

[215] R. Huiskes, R. Rulmerman, G. H. van Lenthe, and J. D. Janssen, "Effects of mechanical forces on maintenance and adaptation of form in trabecular bone," Nature, vol. 405, no. 6787, pp. 704706, 2000.

[216] R. Ruimerman, P. Hilbers, B. van Rietbergen, and R. Huiskes, "A theoretical framework for strain-related trabecular bone maintenance and adaptation," Journal of Biomechanics, vol. 38, no. 4, pp. 931-941, 2005.

[217] Y. Cao, G. Mitchell, A. Messina et al., "The influence of architecture on degradation and tissue ingrowth into threedimensional poly(lactic-co-glycolic acid) scaffolds in vitro and in vivo," Biomaterials, vol. 27, no. 14, pp. 2854-2864, 2006. 
[218] M. W. Laschke, A. Strohe, C. Scheuer et al., "In vivo biocompatibility and vascularization of biodegradable porous polyurethane scaffolds for tissue engineering," Acta Biomaterialia, vol. 5, no. 6, pp. 1991-2001, 2009.

[219] A. A. Deschamps, A. A. van Apeldoorn, H. Hayen et al., "In vivo and in vitro degradation of poly(ether ester) block copolymers based on poly(ethylene glycol) and poly(butylene terephthalate)," Biomaterials, vol. 25, no. 2, pp. 247-258, 2004.

[220] H. Tsuji and K. Ikarashi, "In vitro hydrolysis of poly(L-lactide) crystalline residues as extended-chain crystallites. Part I: Longterm hydrolysis in phosphate-buffered solution at $37^{\circ} \mathrm{C}$," Biomaterials, vol. 25, no. 24, pp. 5449-5455, 2004.

[221] C. J. Kirkpatrick, K. Peters, M. I. Hermanns et al., "In vitro methodologies to evaluate biocompatibility: status quo and perspective," ITBM-RBM, vol. 26, no. 3, pp. 192-199, 2005.

[222] B. Vailhé, D. Vittet, and J.-J. Feige, "In vitro models of vasculogenesis and angiogenesis," Laboratory Investigation, vol. 81, no. 4, pp. 439-452, 2001.

[223] H. Kim, R. P. Camata, S. Chowdhury, and Y. K. Vohra, "In vitro dissolution and mechanical behavior of c-axis preferentially oriented hydroxyapatite thin films fabricated by pulsed laser deposition," Acta Biomaterialia, vol. 6, no. 8, pp. 3234-3241, 2010.

[224] P. Buma, W. Schreurs, and N. Verdonschot, "Skeletal tissue engineering-from in vitro studies to large animal models," Biomaterials, vol. 25, no. 9, pp. 1487-1495, 2004.

[225] Y. Kang, Y. Yao, G. Yin et al., "A study on the in vitro degradation properties of poly(l-lactic acid) $/ \beta$-tricalcuim phosphate(PLLA $/ \beta$-TCP) scaffold under dynamic loading," Medical Engineering and Physics, vol. 31, no. 5, pp. 589-594, 2009.

[226] C. A. Chung, T.-H. Lin, S.-D. Chen, and H.-I. Huang, "Hybrid cellular automaton modeling of nutrient modulated cell growth in tissue engineering constructs," Journal of Theoretical Biology, vol. 262, no. 2, pp. 267-278, 2010.

[227] J.-T. Schantz, A. Brandwood, D. W. Hutmacher, H. L. Khor, and K. Bittner, "Osteogenic differentiation of mesenchymal progenitor cells in computer designed fibrin-polymer-ceramic scaffolds manufactured by fused deposition modeling," Journal of Materials Science: Materials in Medicine, vol. 16, no. 9, pp. 807-819, 2005.

[228] J. Pierre, B. David, K. Oudina, H. Petite, C. Ribreau, and C. Oddou, "Modeling of large bone implant culture in a perfusion bioreactor," Journal of Biomechanics, vol. 39, supplement 1, p. S220, 2006

[229] P. Miranda, A. Pajares, and F. Guiberteau, "Finite element modeling as a tool for predicting the fracture behavior of robocast scaffolds," Acta Biomaterialia, vol. 4, no. 6, pp. 1715-1724, 2008.

[230] S. V. Komarova, "Bone remodeling in health and disease: lessons from mathematical modeling," Annals of the New York Academy of Sciences, vol. 1068, no. 1, pp. 557-559, 2006.

[231] J. A. Sanz-Herrera and E. Reina-Romo, "Cell-biomaterial mechanical interaction in the framework of tissue engineering: insights, computational modeling and perspectives," International Journal of Molecular Sciences, vol. 12, no. 11, pp. 8217-8244, 2011.

[232] J. A. Sanz-Herrera, J. M. García-Aznar, and M. Doblaré, “On scaffold designing for bone regeneration: a computational multiscale approach," Acta Biomaterialia, vol. 5, no. 1, pp. 219229, 2009

[233] H. Kang, C.-Y. Lin, and S. J. Hollister, “Topology optimization of three dimensional tissue engineering scaffold architectures for prescribed bulk modulus and diffusivity," Structural and Multidisciplinary Optimization, vol. 42, no. 4, pp. 633-644, 2010.

[234] D. Lacroix, J. A. Planell, and P. J. Prendergast, "Computer-aided design and finite-element modelling of biomaterial scaffolds for bone tissue engineering," Philosophical Transactions of the Royal Society A: Mathematical, Physical and Engineering Sciences, vol. 367, no. 1895, pp. 1993-2009, 2009.

[235] J. A. Sanz-Herrera, J. M. García-Aznar, and M. Doblaré, "A mathematical approach to bone tissue engineering," Philosophical Transactions of the Royal Society of London. Series A. Mathematical, Physical and Engineering Sciences, vol. 367, no. 1895, pp. 2055-2078, 2009.

[236] D. P. Byrne, P. J. Prendergast, and D. J. Kelly, "Optimisation of scaffold porosity using a stochastic model for cell proliferation and migration in mechanobiological simulations," Journal of Biomechanics, vol. 39, supplement 1, pp. S413-S414, 2006.

[237] P. Swider, M. Conroy, A. Pédrono et al., "Use of high-resolution MRI for investigation of fluid flow and global permeability in a material with interconnected porosity," Journal of Biomechanics, vol. 40, no. 9, pp. 2112-2118, 2007.

[238] K. Karunratanakul, J. Schrooten, and H. van Oosterwyck, "Finite element modelling of a unilateral fixator for bone reconstruction: Importance of contact settings," Medical Engineering and Physics, vol. 32, no. 5, pp. 461-467, 2010.

[239] J. A. Sanz-Herrera, J. M. García-Aznar, and M. Doblaré, "Micromacro numerical modelling of bone regeneration in tissue engineering," Computer Methods in Applied Mechanics and Engineering, vol. 197, no. 33-40, pp. 3092-3107, 2008.

[240] K. S. Chan, W. Liang, W. L. Francis, and D. P. Nicolella, "A multiscale modeling approach to scaffold design and property prediction," Journal of the Mechanical Behavior of Biomedical Materials, vol. 3, no. 8, pp. 584-593, 2010.

[241] H. Ye, D. B. Das, J. T. Triffitt, and Z. Cui, "Modelling nutrient transport in hollow fibre membrane bioreactors for growing three-dimensional bone tissue," Journal of Membrane Science, vol. 272, no. 1-2, pp. 169-178, 2006.

[242] T. S. Karande, J. L. Ong, and C. M. Agrawal, "Diffusion in musculoskeletal tissue engineering scaffolds: design issues related to porosity, permeability, architecture, and nutrient mixing," Annals of Biomedical Engineering, vol. 32, no. 12, pp. 1728-1743, 2004. 


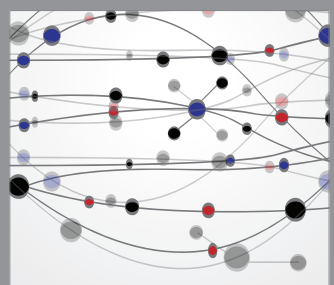

The Scientific World Journal
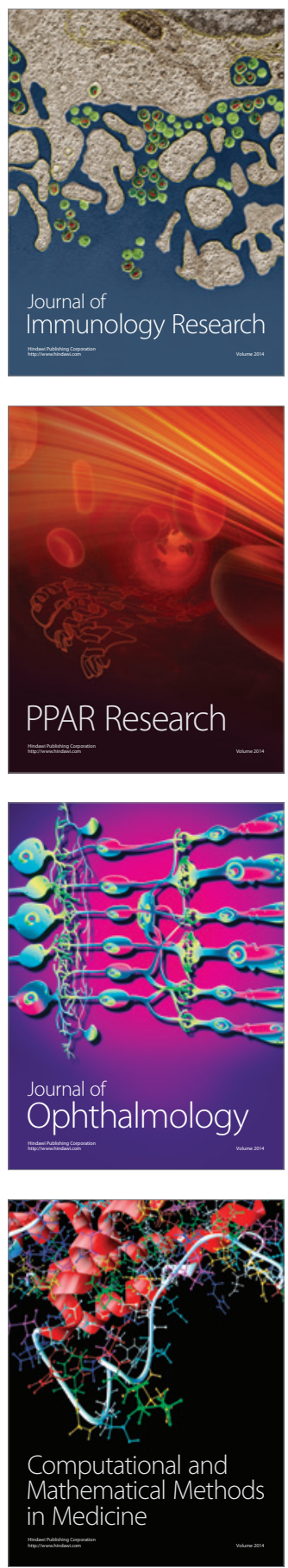

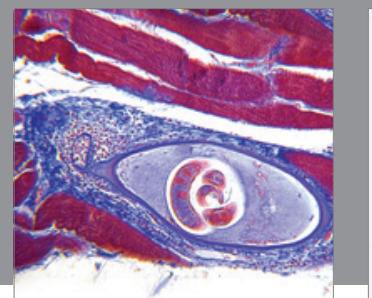

Gastroenterology

Research and Practice
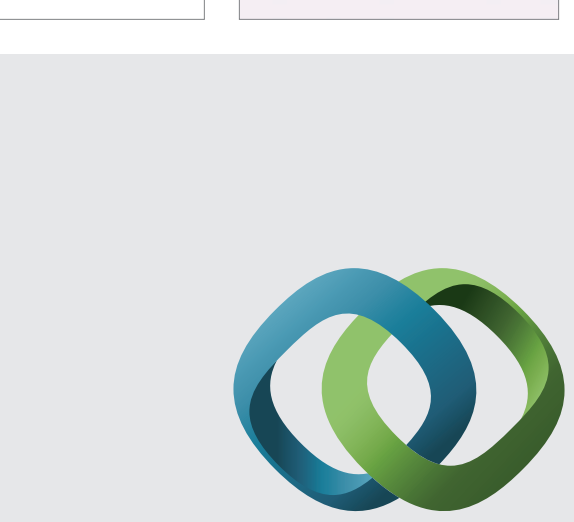

\section{Hindawi}

Submit your manuscripts at

http://www.hindawi.com
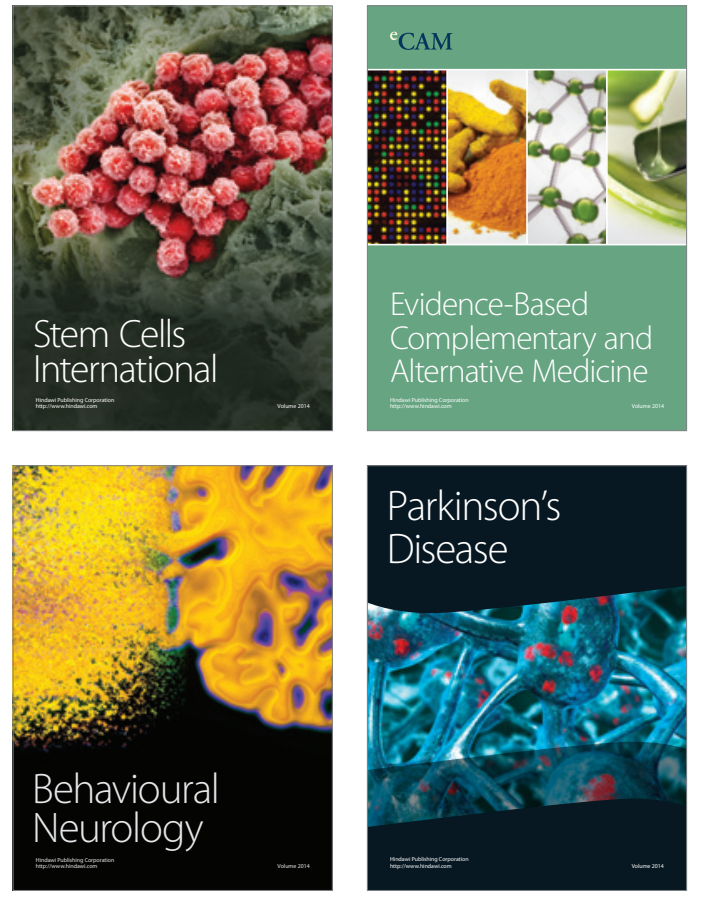
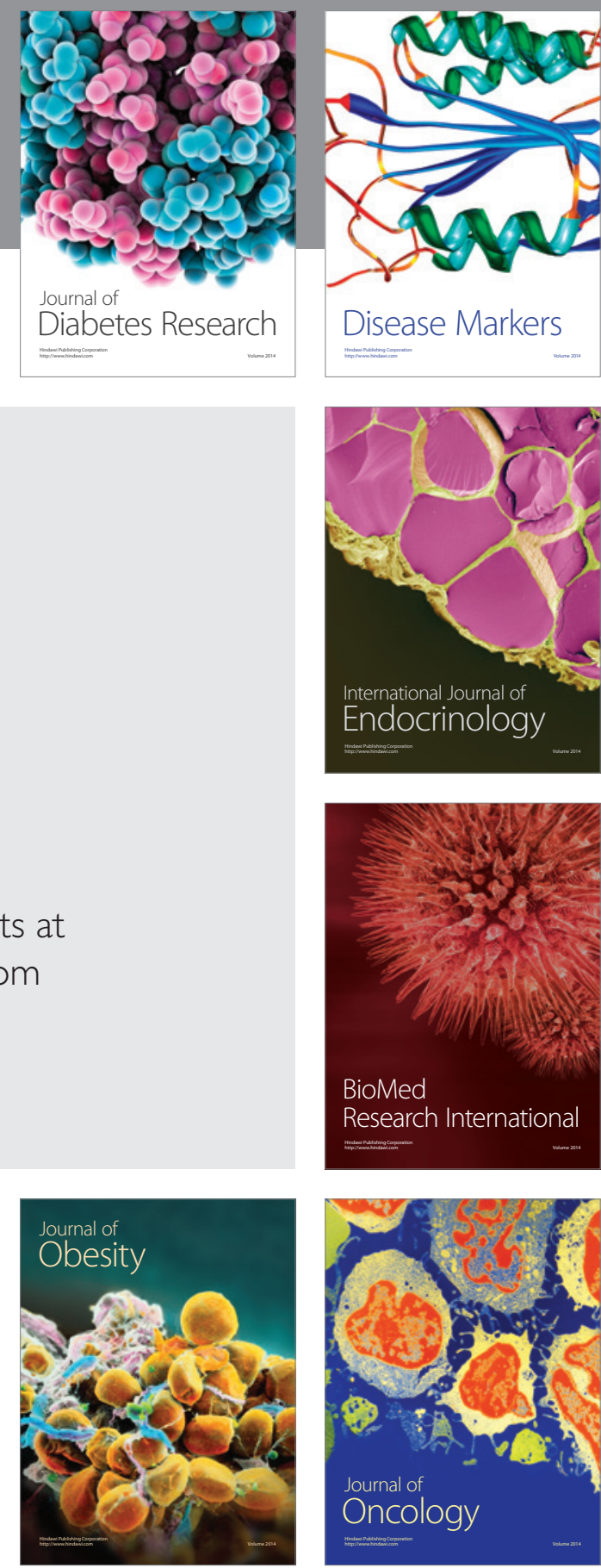

Disease Markers
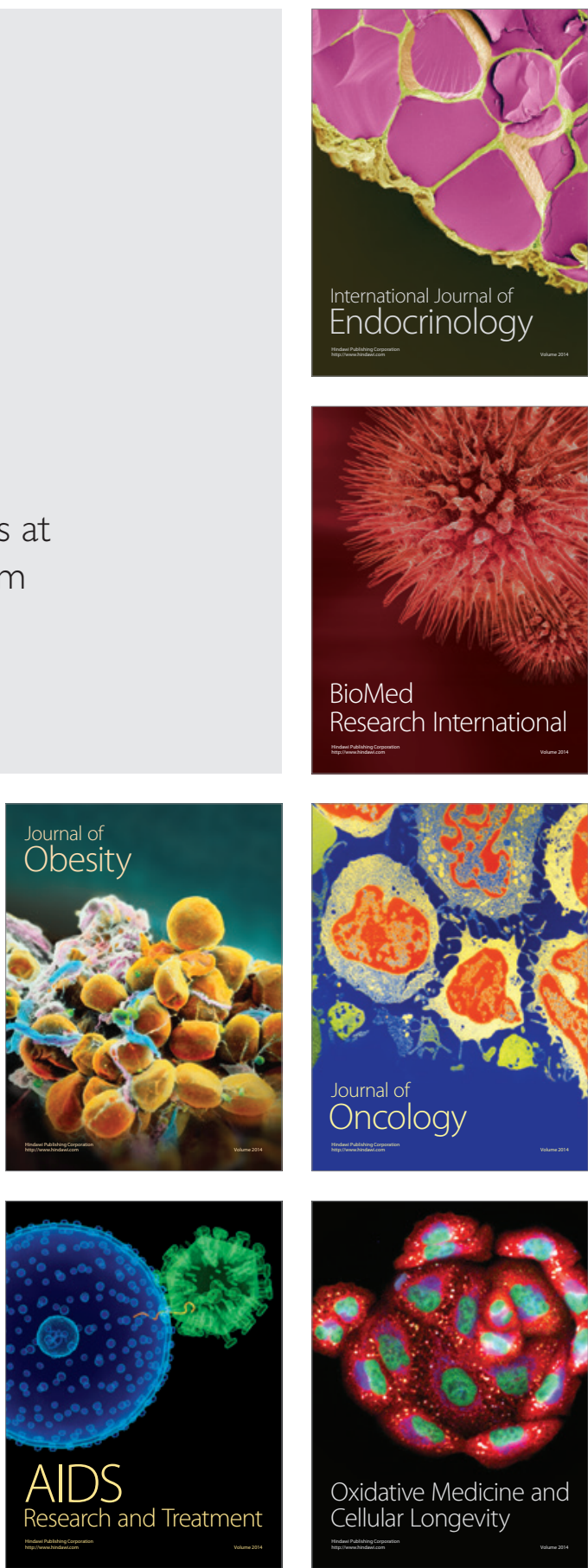